\title{
UPGRADING AN INTERMITTENT \& BRANCHED WATER NETWORK TO A CONTINUOUS \& LOOPED NETWORK: A CASE STUDY IN COASTAL PERU
}

Jennifer A. O'Neill

Michigan Technological University

Follow this and additional works at: https://digitalcommons.mtu.edu/etds

Part of the Civil and Environmental Engineering Commons

Copyright 2012 Jennifer A. O'Neill

Recommended Citation

O'Neill, Jennifer A., "UPGRADING AN INTERMITTENT \& BRANCHED WATER NETWORK TO A CONTINUOUS \& LOOPED NETWORK: A CASE STUDY IN COASTAL PERU", Master's report, Michigan Technological University, 2012.

https://doi.org/10.37099/mtu.dc.etds/612

Follow this and additional works at: https://digitalcommons.mtu.edu/etds

3 Part of the Civil and Environmental Engineering Commons 


\title{
UPGRADING AN \\ INTERMITTENT \& BRANCHED WATER NETWORK \\ TO A CONTINUOUS \& LOOPED NETWORK: \\ A CASE STUDY IN COASTAL PERU
}

By

Jennifer A. O’Neill

\begin{abstract}
A REPORT
Submitted in partial fulfillment of the requirements for the degree of MASTER OF SCIENCE

In Environmental Engineering
\end{abstract}

MICHIGAN TECHNOLOGICAL UNIVERSITY

2012

(C) 2012 Jennifer A. O’Neill 
This report has been approved in partial fulfillment of the requirements for the Degree of MASTER OF SCIENCE in Environmental Engineering.

Department of Civil \& Environmental Engineering

\author{
Report Advisor: $\quad$ Dr. Brian Barkdoll \\ Committee Member: $\quad$ Dr. Kurt Paterson \\ Committee Member: $\quad$ Dr. Carol MacLennan
}

Department Chair: $\quad$ Dr. David Hand 


\section{Table of Contents}

List of Figures............................................................................................................................................... iv

List of Tables ..................................................................................................................................... vi

Abstract........................................................................................................................ vii

1.0 Introduction............................................................................................................................................. 1

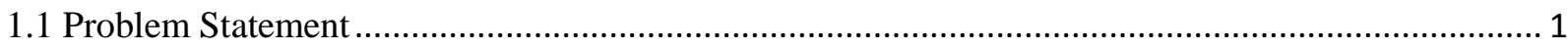

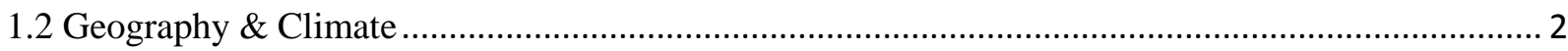

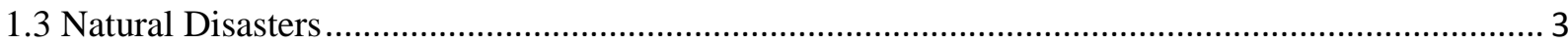

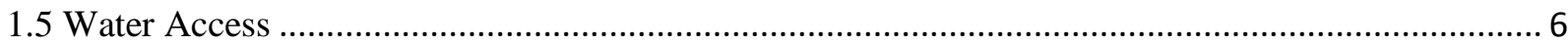

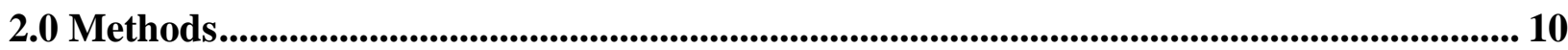

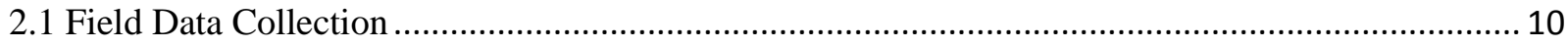

2.2 Creating a Continuous Service Model …………………………………………………….... 13

2.3 Creating a Looped Network................................................................................................ 16

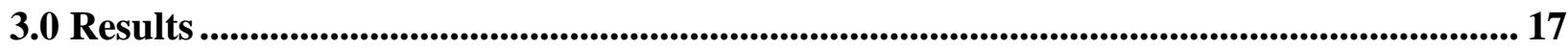

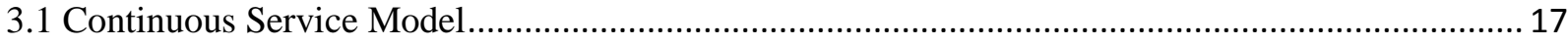

3.2 Looped Network Model ............................................................................................. 22

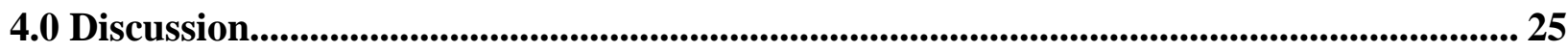

5.0 Future Work ................................................................................................................................. 26

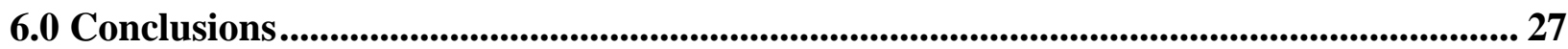

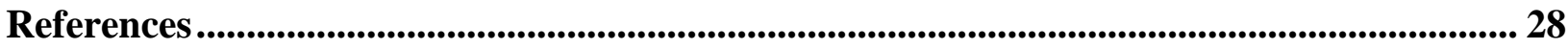

Appendix A Handheld GPS Data ................................................................................................... 31

Appendix B Pipe Data ................................................................................................................. 32

Appendix C Water Consumption ................................................................................................. 33

Appendix D Nodal Demand ........................................................................................................ 35

Appendix E List of Supplemental EPANET Reports................................................................... 36

Appendix F List of Supplemental Spreadsheet .................................................................................. 39 


\section{List of Figures}

Figure 1 The Cost of Coping with Intermittent Water Supply, Case Study from India (Chary, 2009)

Figure 2 National Map of Peru, Cerro Prieto is about $10 \mathrm{~km}$ North of Ica (CIA World Factbook -

South America - Peru)

Figure 3 USGS ShakeMap of the 2007 Earthquake (Magnitude 8.0 - NEAR THE COAST OF CENTRAL PERU, 2007).....

Figure 4 Residential Plots Registered by the Municipality versus Actual Residences Boxed in Red (Guadalupe, 2012) (GoogleEarth, 2012) ..................................................................... 6

Figure 5 Cerro Prieto, View of Elevated Water Tank (O'Neill, 2012)........................................ 8

Figure 6 Residential Water Storage Tank on Rooftop (O'Neill, 2012)..................................... 9

Figure 7 Water Storage Containers Vulnerable to Contamination Due to Missing Lid and Dirty Dipping Bucket (O'Neill, 2012).

Figure 8 View of the Elevated Water Tank from the Highest Point in the Water Network Punta Hermosa (O'Neill, 2012)

Figure 9 The Operator must Manually Open Valves for Branches of the Water Network (O'Neill, 2012) 12

Figure 10 The Pump House Includes the Pump, Well Cap, and Chlorine Gas Injection System in Background (O'Neill, 2012).......

Figure 11 EPANET Model of Cerro Prieto Water Network with Aerial Image Backdrop (GoogleEarth, 2012)

Figure 12 Adjusted Demand Pattern with Large Mid-day Peak

Figure 13 A Resident Stores Water in Typical Containers (O'Neill, 2012).

Figure 14 EPANET Model Displaying the As-Built Scenario \& Node Elevations. Points with Pressures Below 20 PSI Are All in Punta Hermosa. 
Figure 15 Number of Pressure Violations vs. Water Network Scenario

Figure 16 Number of Pressure Violations vs. Water Network Scenario with Bypass .....

Figure 17 Diagram of Well-Pump-Tank Setup with Bypass Piping and Increased Tank Height. 21

Figure 18 Screenshot of EPANET Rule Based Control for Pump Operation and Tank Water Level ......

Figure 19 Proposed Loop Connections. The Health Clinic and School Are Marked with a Cross

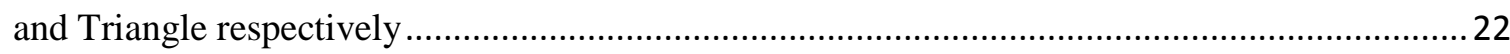

Figure 20 Estimated Future Groundwater Levels (Postigo, 2012)............................................ 27 


\section{List of Tables}

Table 1 Water Access Based on 2007 Census Responses (Censos Nacionales 2007 Perú)

Table 2 Satisfaction with Water Service in Cerro Prieto ............................................... 8

Table 3 Chemical and Biological Characteristics of Cerro Prieto Well Water (EMAPASalas, Analisis de Calidad del Agua de Pozo, 2012)..................................... 13

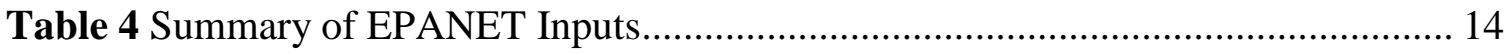

Table 5 Summary of Model Scenarios, Pressure Violations, and Cost........................... 19

Table 6 Summary of Loop Analysis (*No Feasible Solution) ...................................... 23

Table 7 Ranking of Loops Based on Total User Benefited Method

(*No Feasible Solution)

Table 8 Ranking of Loops for Each Vulnerable User Facility using Vulnerable User Benefitted Method, Loops Benefitting Zero Vulnerable Users are Excluded (*No Feasible Solution)

Table 9 Ranking of Loops with Weighting of Vulnerable \& Total Users Benefiting ..... 25 


\begin{abstract}
This case study sought to determine how the potable water network of Cerro Prieto, Peru could be improved. The network as it exists now is branched and operated intermittently, exposing residents to water contamination risks and inconvenience. Using EPANET, it was found that the as-built network can support continuous water service, all points could stay over $10 \mathrm{psi}$, and the current water consumption rate could be maintained. To keep all points over 20 psi, the height of elevated water tank must be increased 6 feet, and the pump switched on whenever the tank drains. It was also found that almost the entire community would benefit from several possible closed loops in the network, but the high cost gives downstream loops higher priority. Due to the scarcity of water in the region, the first action must be assessing the well capacity, and a water conservation plan that may include water meters.
\end{abstract}




\subsection{Introduction}

This report is a case study of Cerro Prieto, a small community in southern Peru. The author was able to collect information for this report as a U.S. Peace Corps volunteer assigned to the district that includes Cerro Prieto.

\subsection{Problem Statement}

All communities must balance providing adequate water service with environmental, economic, and social constraints. The nature of these constraints can vary wildly, and Peru is no exception. The water utility in Cerro Prieto has tried to balance extremely limited water supplies and small budgets by limiting water service to intermittent operation and building few redundancies in their water infrastructure. This leaves residents subject to various risks and disadvantages.

Water provided intermittently can be contaminated by groundwater due to negative pressures in the piping, or contaminated while it is being stored by residents between water service events. In the district, $20 \%$ of the population is already struggling with poverty (Censos Nacionales 2007 Perú) and malnutrition; for them water-borne illnesses are especially hard to overcome. The lack of redundancy means an emergency (such as an earthquake) could more readily stop water from reaching residents. A member of each household has to dedicate their time to managing the household water. Parts in the network will have shorter lifespans due to more intense wear. It is possible more water is wasted because users are pressured to overstore water (Pandit). Residents pay flat rates but receive very different levels of water access. Finally, as shown in Figure 1 , the cost of coping disproportionality affects residents below the poverty level (Chary, 2009).

The objective of this report is determine if the as-built water network, which is currently operated intermittently, can support continuous water service. This includes what improvements could be made to network components to ensure adequate water pressure at all points and times. Additionally this report analyzes the cost-benefit of installing additional connecting pipes to create redundancies. 


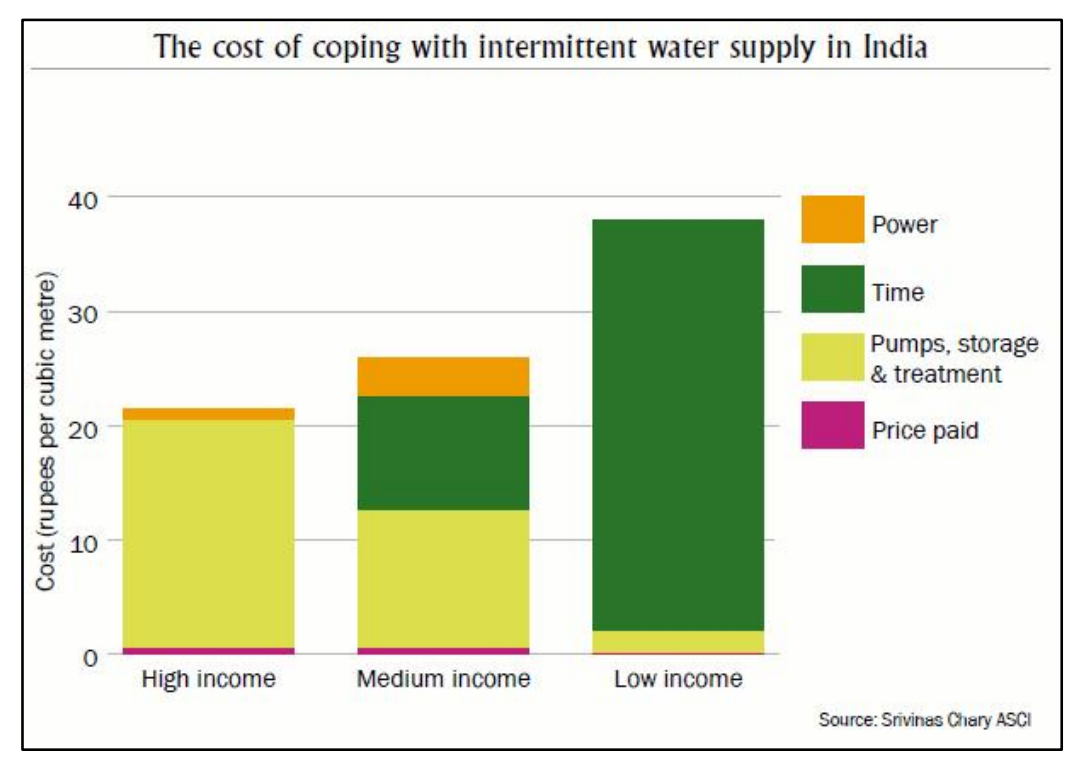

Figure 1 The Cost of Coping with Intermittent Water Supply, Case Study from India (Chary, 2009)

\subsection{Geography \& Climate}

Peru can be divided into three regions: the jungle to the east (selva), the Andes in the center (sierra), and the coastal desert to the west (costa). The water system discussed in this report is located in the costal desert, more specifically, in the department of Ica. Ica is immediately south of Lima, and is part of the southern coastal region. This has several implications in the consideration of this water network.

The community of Cerro Prieto is in the district of Salas Guadalupe, in the department of Ica. It is also just a short commute outside of the departmental capital of Ica, also named Ica (see Figure 2). The city of Ica is developing rapidly and has over two hundred thousand residents. The primary highway in Peru, the Pan-American Highway, goes past Cerro Prieto. Due to the highway, residents of Cerro Prieto have access to the city of Ica, and the city of Lima which is about 200 miles to the north. 


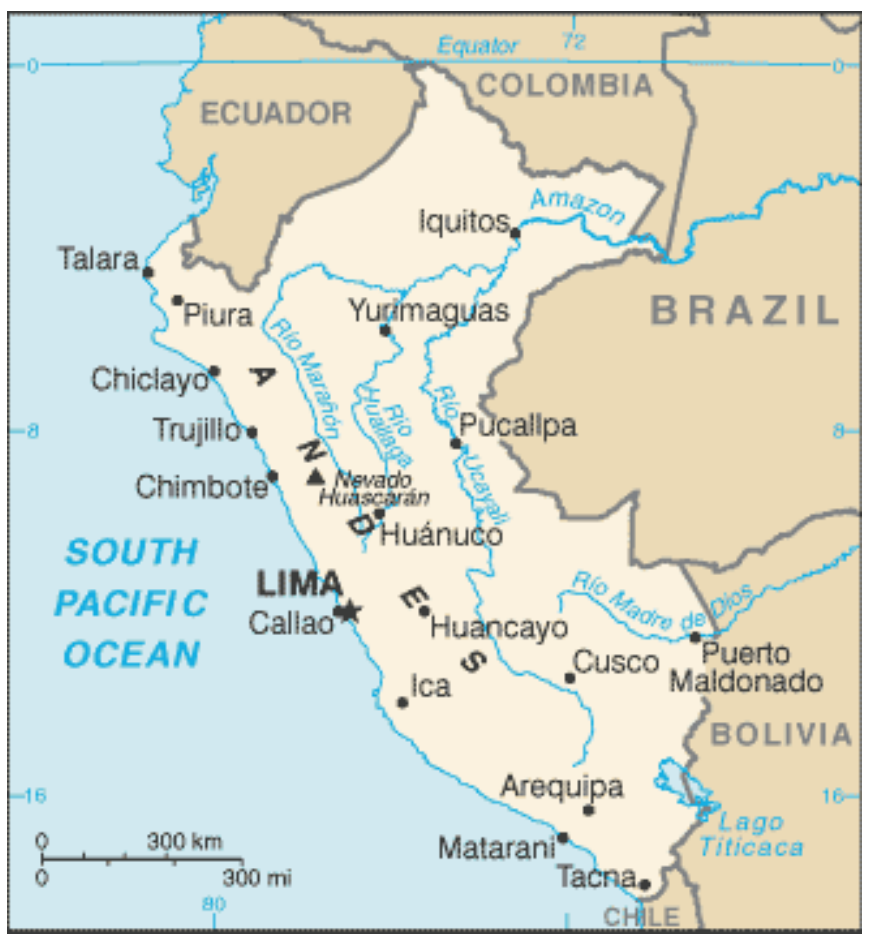

Figure 2 National Map of Peru, Cerro Prieto is about $10 \mathrm{~km}$ North of Ica (CIA World Factbook - South America - Peru)

The climate can be described as coastal desert. Some references include Peru's southern coastal desert as part of the more well know Atacama Desert of northern Chile. The annual precipitation is around 0.9 inches (Ica Weather, Peru Weather Averages). There are seasons, but a generally consistent climate. The average low temperature in the winter is $57 \mathrm{~F}$, and the average summer high is $85 \mathrm{~F}$. The area experiences the rainy season of January-February in the nearby Andes indirectly, as this is the only time of the year the Ica River has water in it

\subsection{Natural Disasters}

The Pacific Ocean is notoriously surrounded by “The Ring of Fire”, a loop of coasts with numerous volcanoes and strong seismic activity. Peru, located on the western coast of South America, is part of this massive series of faults. Earthquakes are a frequent phenomenon in Peru; however a 2007 earthquake devastated the department of Ica. 
The earthquake had a measured magnitude of 8.0 (Magnitude 8.0 - NEAR THE COAST OF CENTRAL PERU, 2007) and was centered near the coastal city of Pisco, about $100 \mathrm{~km}$ northwest of Salas Guadalupe (see Figure 3). It is estimated 514 people died and over 1000 more injured. There were also massive utility outages, closed transportation routes, and 35,500 buildings destroyed. Tragically the earthquake struck in the early evening, just as many Peruvians gathered for evening mass. The predominant building material in the region is adobe brick, which has little shear strength against a seismic event.

Due to the massive damage caused by the earthquake, the response effort was hampered. The extent of the damage was not initially clear. More than one month after the earthquake, response groups were still responding to initial needs. For example, almost one month after the earthquake USAID airlifted rolls of plastic tarp for construction of temporary housing (USAID Assists Peru After Devastating Earthquake, 2007). The earthquake left many long term scars behind: piles of rubble, churches and many other community buildings destroyed in the event have not been rebuilt, along with damaged utilities infrastructure. The Peruvian Department of Civil Defense has since launched a preparedness campaign, including handouts listing items for an earthquake response bag, drills, and how to identify safe locations in your home.

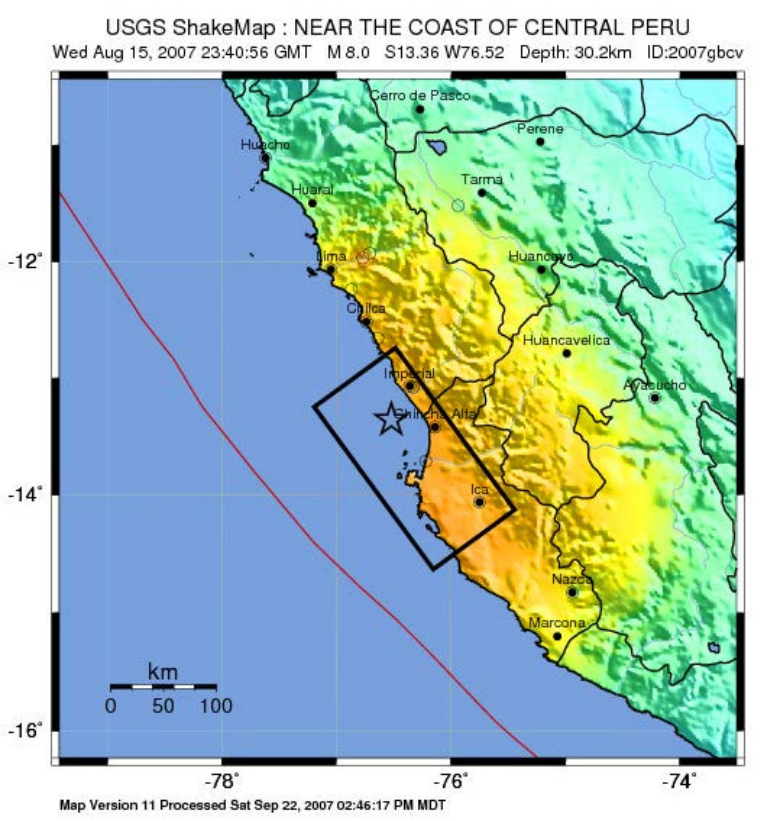

Figure 3 USGS ShakeMap of the 2007 Earthquake (Magnitude 8.0 - NEAR THE COAST OF CENTRAL PERU, 2007) 
The Peruvian government needs to take earthquake preparation into its long term city planning. In January of 2012, a smaller earthquake than the one in 2007 took place which again damaged the sewer system (Very strong dangerous earthquake near Ica, Peru, 2012). Ica and its government officials were not adequately prepared for an event of this nature, and its response took much longer than it would have had they had a plan in place.

\subsection{Social \& Economic Background}

Ica has an ideal climate to grow crops year round. The World Bank has lent millions of dollars to agro-companies in order to encourage food exports (Schmall, 2010). Despite the scarcity of water, the area supports many "fundos" or large industrial farms. Primarily they grow grapes for the production of wine and Pisco, but also cotton, citrus fruits, apples, and asparagus for export. In the 2007 census, the population of the district of Salas Guadalupe was 17,973 (Censos Nacionales 2007 Perú). Of those older than 14 years, the number with jobs was 7,729 (5,274 of which are men). Agriculture provides $60 \%$ of the jobs. The district has several new residential areas due to a steadily increasing population. There is significant immigration from the mountains to the east due to the availability of work. Most recently the Municipal government of Salas Guadalupe has estimated the population to be near 20,000.

Salas, Guadalupe was founded in 1925 and has a long history of growing grapes for fermenting and making into a liquor called pisco. Salas was traditionally a small community in the desert but recently has experienced an agricultural boom. This has brought an influx of new people. The Peruvian national census no longer collects data on ethnicity; however a majority of the people migrating would describe themselves as Mestizo, a mix of Spanish and Peruvian heritage. The district is a mix of Coastal and Sierra culture. Peru has two national languages: Spanish and Quechua. Quechua is a native Peruvian language typically spoken by the Sierra culture, and is occasionally heard in Guadalupe.

The Sierra culture has a strong sense of community and migrants from the sierra continue community events such as collectively building a Wawawasi (kindergarten school) after their workdays. The primary religion of the area is Catholicism, and it has incorporated traditional Peruvian aspects into its practice. Numerous religious holidays and festivals are celebrated. There are several unique traditions like elaborate towers laden with fireworks, Peruvian food, and grand processions.

In Peru families can gain ownership of property by inhabiting it for a certain amount of time and if there is no protest by the original land owner. Salas Guadalupe has seen a recent population boom due to this policy combined with the 
increase in local demand for agriculture workers. Many of the new neighborhoods in the district have been settled by migrant workers from the mountainous departments to the east, such as Huancavelica and Ayacucho.

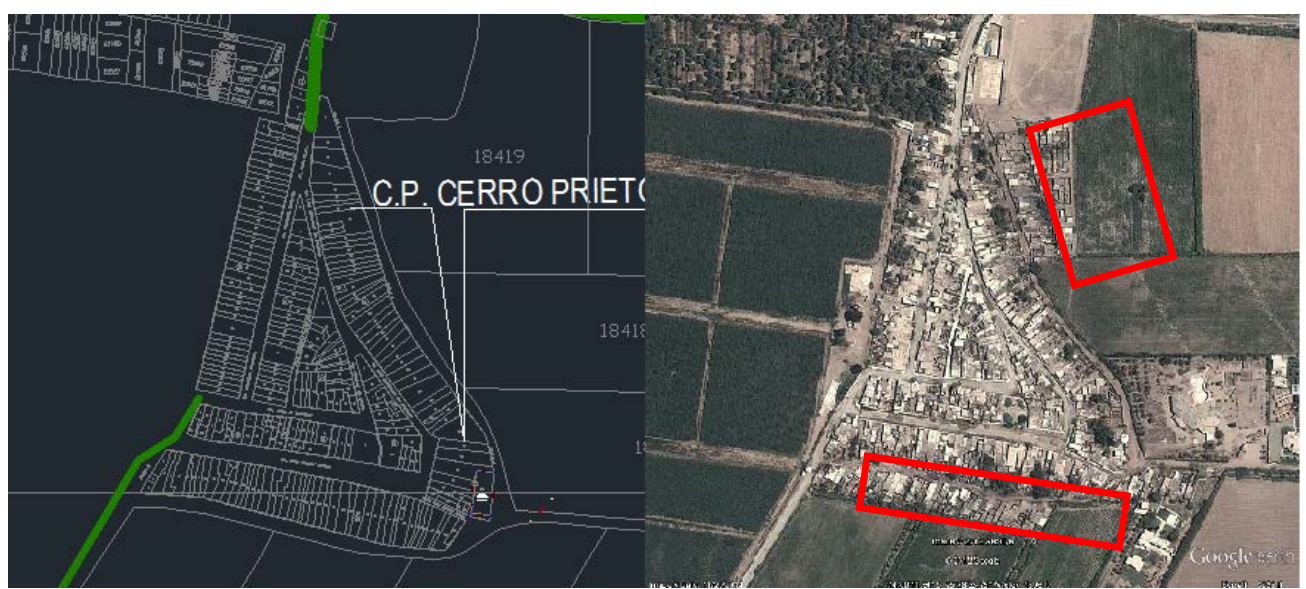

Figure 4 Residential Plots Registered by the Municipality versus Actual Residences Boxed in Red (Guadalupe, 2012) (GoogleEarth, 2012)

In some cases new settlements appear over night as new groups of people arrive, these are called invasions. These settlements are generally seen as unfavorable by the older local population. They are often viewed as sources of crime and disease. Residents in the new settlements cannot always gain immediate access to public utilities and services due to the vague property ownership. Once a family has title to their plot they may connect to electric, water and sewer lines. As shown in Figure 4, there is a discrepancy between the residential plots recorded by the Municipality, and the actual number of households in Cerro Prieto. The municipal government can also act as barrier to utilities access by providing different levels of service to different neighborhoods.

\subsection{Water Access}

In Peru in the early 1990's, the responsibility to provide potable water was passed down to municipal governments or community boards. Many created water and wastewater municipal businesses which have had mixed success. Some lack training and experience managing water networks. The public gained the responsibility of paying for water service, but did not gain any input towards the management of their water service (Pojman, 2006). 
In Salas Guadalupe, potable water service is available thru a semi-autonomous water \& wastewater company referred to as EMAPA Salas (Empresa Municipal de Agua Potable y Alcantarillado or Municipal Water and Wastewater Company). EMAPA Salas is financially separate from the municipality; however the mayor has authority over the EMAPA Gerente, or manager. Also the position of Gerente is a political appointment, and it is common to have high staff turnover along with a newly elected mayor. EMAPA provides water connections to almost all of the various neighborhoods that comprise Salas Guadalupe.

Once a household has established residency, it can request water service from EMAPA. Users pay a one-time connection fee for the construction of the shut-off box, and then pay a flat monthly fee afterwards. Monthly rates range from 8 to 12 Nuevo Soles (about 3.00 to 4.50 U.S. Dollars) based on what neighborhood the resident is in. Each neighborhood in the district of Salas Guadalupe has its own water infrastructure. Each has a deep well as the water source, a pump, elevated water tower (see Figure 5), and piped distribution system. Areas of newly settled homes, generally invasions, have temporary public faucets at each corner until residents have property titles. Then the municipality will construct municipal services including water lines (see Table 1)

Table 1 Water Access Based on 2007 Census Responses (Censos Nacionales 2007 Perú)

\begin{tabular}{|c|c|c|c|}
\hline Water Access & Salas Guadalupe & Ica & Peru \\
\hline \multirow{2}{*}{ Water Tap Inside the House } & 2466 & 107598 & 3504658 \\
\cline { 2 - 4 } & $87 \%$ & $84 \%$ & $81 \%$ \\
\hline \multirow{2}{*}{ Water tap Inside the Property } & 360 & 15210 & 568800 \\
\cline { 2 - 4 } & $13 \%$ & $12 \%$ & $13 \%$ \\
\hline \multirow{2}{*}{ Public Water Tap } & 21 & 6032 & 243241 \\
\cline { 2 - 4 } & $1 \%$ & $5 \%$ & $6 \%$ \\
\hline Sum & 2847 & 128840 & 4316699 \\
\hline
\end{tabular}

The quality of water service varies significantly between neighborhoods. Central Guadalupe receives nearly continuous water service, with few complaints of low water pressure. Residents of Cerro Prieto are generally content with their water service (see survey results in Table 2), however the service there is not equal. Residents there typically receive 3 days of water service per week. Further compounding the limited days of water, the system in Cerro Prieto is branched, and each branch is only opened for a short period of about 2 hours. Due to the location of some households upstream of the control valves, they have much longer periods of access to water. Additionally a cluster of homes called Punta Hermosa are slightly elevated from central Cerro Prieto, and consistently experience lower water pressures. 
Table 2 Satisfaction with Water Service in Cerro Prieto

(EMAPASalas, Diagnóstico, 2012)

\begin{tabular}{|c|c|c|c|c|}
\hline Survey Question & Good & Regular & Bad & Sum \\
\hline \multirow{2}{*}{ How is the water quantity? } & 21 & 15 & 2 & 38 \\
\cline { 2 - 5 } & $55 \%$ & $39 \%$ & $5 \%$ & $100 \%$ \\
\hline \multirow{2}{*}{ How is the water quality? } & 28 & 10 & 0 & 38 \\
\cline { 2 - 5 } & $74 \%$ & $26 \%$ & $0 \%$ & $100 \%$ \\
\hline
\end{tabular}

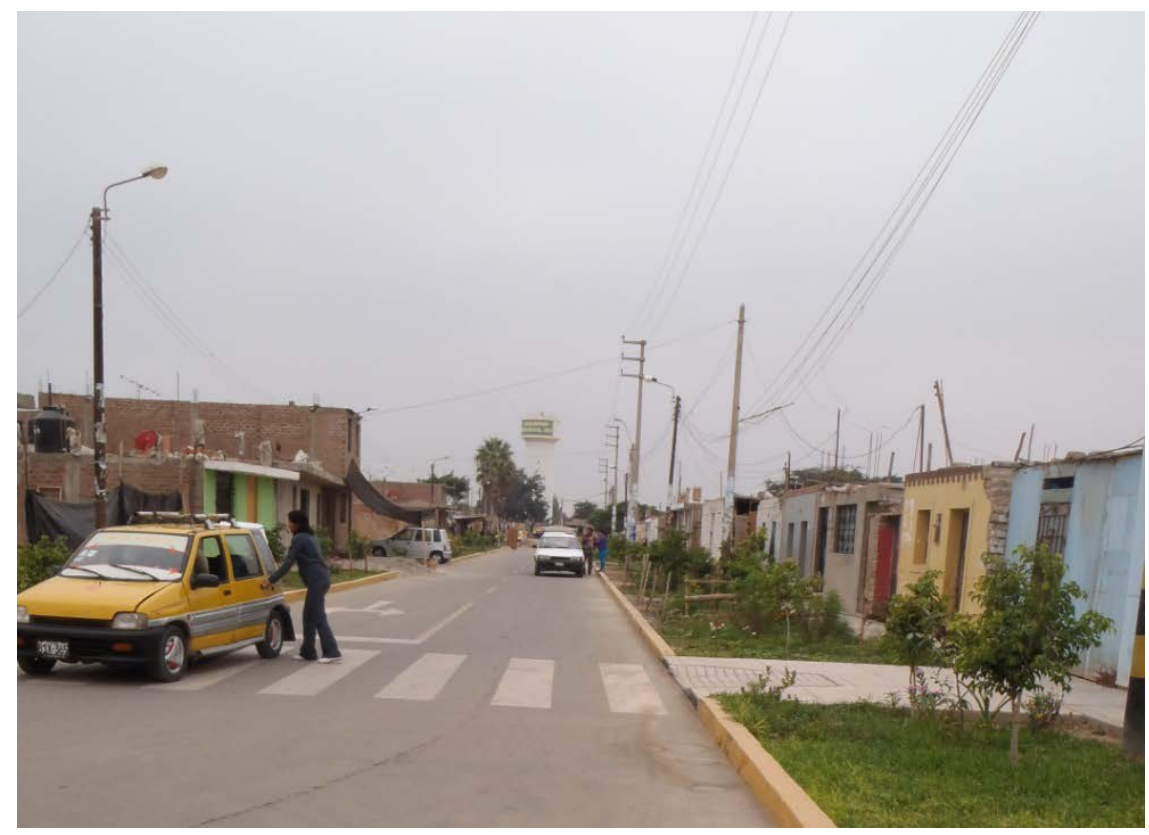

Figure 5 Cerro Prieto, View of Elevated Water Tank (O'Neill, 2012)

The branched nature of the water network limits the adaptability of the network. For whatever reason a pipe may need to be closed (maintenance, failure) all downstream users must lose access. The vulnerability of a network can be mitigated by creating redundancies. This is typically accomplished by adding connectors between branches, creating loops. Addressing this vulnerability of the network could make a crucial difference in extreme events, such as after an earthquake when large amounts of water might be needed to put out fires. 
A water system operated intermittently and at low pressures has several negative impacts. First is simple inconvenience. Someone in each household has to stay home and wait for the water to come on. This could mean an adult has to shorten hours of work, or a child stays home from school. Typically women manage household water, and this inconvenience affects them disproportionately. Low pressures also result in lower flows from taps and thus increased times to fill containers. Water might also not be able to reach second stories of homes or raised residential water storage tanks (see Figure 6). The intermittent operation of the system reduces the lifetime of the network. The repetitive changes in pressure in the pipes accelerate wear on the pipes and they will fail sooner.

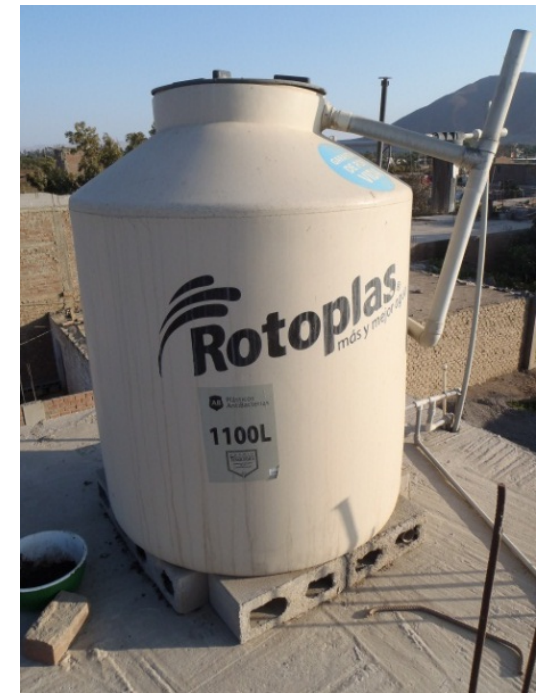

Figure 6 Residential Water Storage Tank on Rooftop (O'Neill, 2012)

The intermittent operation creates additional ways that potable water is wasted. Due to the inconsistent access to water, users overstore water. The author observed all possible containers are filled every time there is water service, and water remaining from the previous service event is dumped in exchange for new, "fresher" water (McIntosh, 2003). Additionally, taps are typically left open; so that users are alerted when water is available. However this means there are inevitably some unattended taps left to waste the water flowing out of them. These losses potentially negate any water savings attempted by operating the system intermittently (WHO, 18. Conservation of water in public and domestic supply systems). 


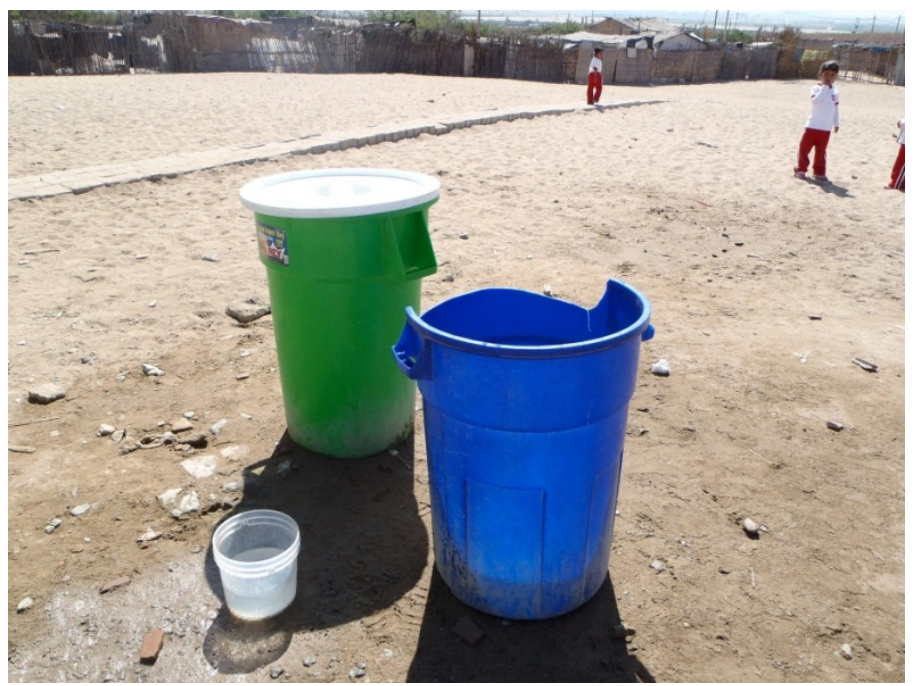

Figure 7 Water Storage Containers Vulnerable to Contamination Due to Missing Lid and Dirty Dipping Bucket (O'Neill, 2012)

The greatest concern is the community health threat. The water network is not constantly pressurized, allowing any surrounding ground water to enter the pipes and contaminate the potable water. Partially flowing networks can even create vacuums pulling in groundwater. Residents are also forced to rely on stored water. Stored water is susceptible to contamination, some common routes of contamination being lost lids, dippers, and animals (see Figure 7). Chemical contamination can also occur if chemical (often pesticide) storage containers are repurposed for water storage (WHO, Guidelines on Management Options for Empty Pesticide Containers, 2008). In Cerro Prieto, the potable water typically is not treated with chlorine, and has no residual disinfection capability. Stored water is especially vulnerable to contamination.

\subsection{Methods}

\subsection{Field Data Collection}

Collecting data in order to assess the Cerro Prieto water network began with interviews with the water provider and water users. After community surveys, it was found that water was typically available 3 days per week, which days sometimes changing. The duration of service per day varied widely based on household location in Cerro Prieto. Some households had water almost all day and at high pressure. Others reported they only received one to two hours of water, and the water came out of their taps very slowly. 
The water provider and operators confirmed these aspects. Besides interviews with the EMAPA manager, the author spent time with the Cerro Prieto operator to observe how the network was operated and maintained. During the days there is water service, the operator begins by rising early and turning on the pump between the well and the water tower (see Figure 8). The well is estimated to be 50 meters deep. After the tank is filled the operator then begins to open valves to different branches of the water network (see Figure 9). During the day the operator walks around Cerro Prieto, opens the valve for a branch for two hours, then closes it and opens the next. Locations of the valves were recorded by the author with a personal GPS unit. The pump is pumping most of the day. The operator did not know of a bypass for the water tower. Water is never stored in the water tower between service days. The storage volume of the water tower was found by climbing up and inside the tower and measuring with a tape measure. The height of the water tower was estimated by the number of rungs on the ladder up to the reservoir. The network pipe material and diameter were based on piping found stored near the pump house. The pump motor was labeled with the manufacturer and model number.

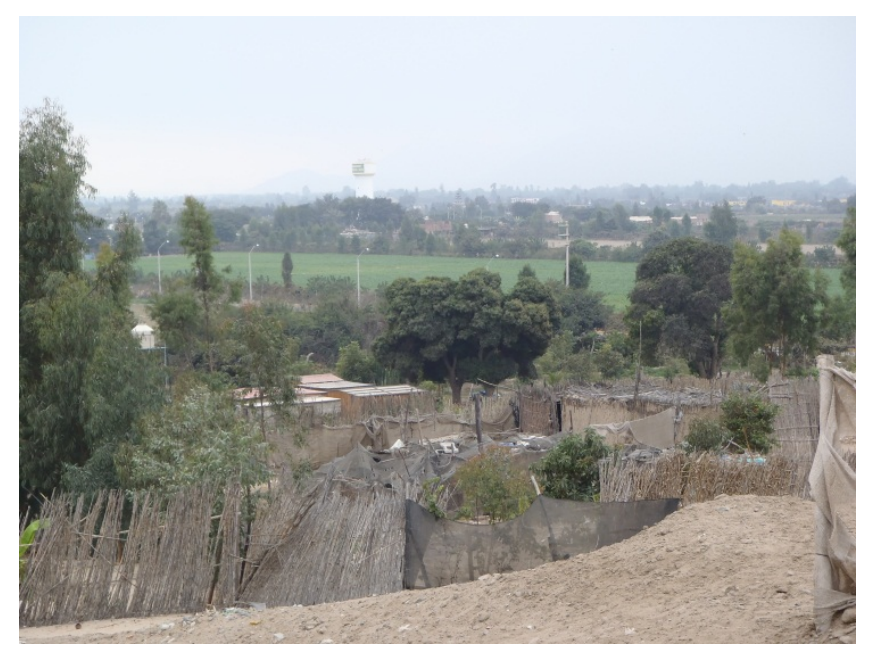

Figure 8 View of the Elevated Water Tank from the Highest Point in the Water Network Punta Hermosa (O'Neill, 2012) 


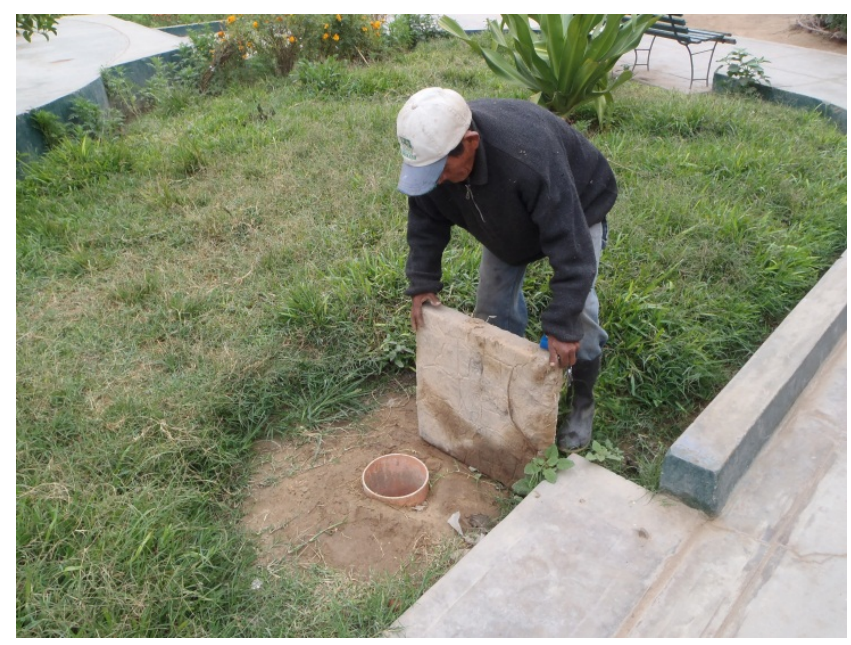

Figure 9 The Operator must Manually Open Valves for Branches of the Water Network (O'Neill, 2012)

A plaque on the front of the pump house indicated the regional government of Ica had been responsible for installing the well, pump, tower, and network, however construction plans or documents for the project were unavailable. The Autoridad Nacional del Agua, the government branch that regulates wells in the area, had no documentation of the well. EMAPA Salas also had no documentation of the Cerro Prieto water system.

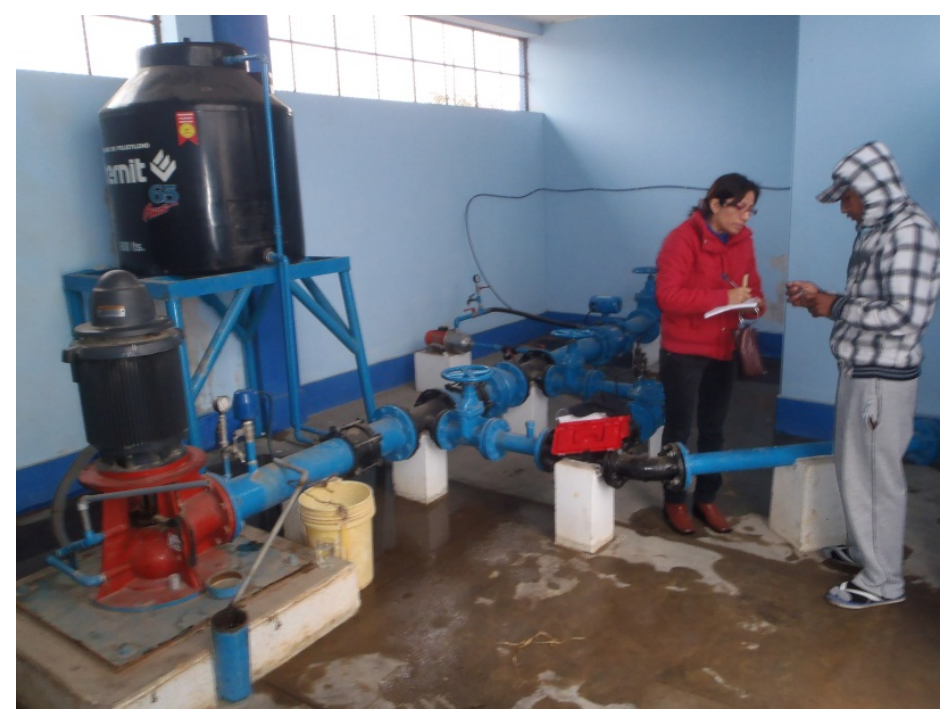

Figure 10 The Pump House Includes the Pump, Well Cap, and Chlorine Gas Injection System in Background (O'Neill, 2012) 
Additionally the pump house has a chlorine gas injection system (see Figure 10), which according to the EMAPA manager was in use. However the author observed that the chlorine gas injection pump was often not turned on. Water sampled directly from the pump house was found to have zero coliform or E. coli colonies (see Table 3). Water samples from the network and household storage tanks were unavailable. This would be useful information for agencies attempting to reduce diarrheal infections by identifying where and when water is contaminated.

\section{Table 3 Chemical and Biological Characteristics of Cerro Prieto Well Water (EMAPASalas, Analisis de Calidad del Agua de Pozo, 2012)}

\begin{tabular}{|c|c|c|c|c|}
\hline $\mathbf{p H}$ & $\begin{array}{c}\text { Conductivity } \\
(\boldsymbol{\mu} \mathbf{S} / \mathbf{c m})\end{array}$ & $\begin{array}{c}\text { Total Hardness } \\
(\mathbf{C a C O 3} \mathbf{~ m g} / \mathbf{L})\end{array}$ & $\begin{array}{c}\text { Total Coliforms } \\
(\mathbf{N M P} / \mathbf{1 0 0} \mathbf{~ m L})\end{array}$ & Temperature (C) \\
\hline 8.48 & 508 & 191.9 & $<1.8$ & 26.4 \\
\hline
\end{tabular}

\subsection{Creating a Continuous Service Model}

In order to assess what in the existing water network would have to be changed to provide continuous water supply, an approximation of the Cerro Prieto water network was created in the program EPANET. Epanet is a public domain software available from the USEPA (EPANET). The user creates a representation of a network in the software workspace. Typical inputs include elevations of key points, pipe lengths, water reservoir levels, tank diameters, demands, material friction factors, pump horsepower, and duration of the trial (see Table 4). EPANET can then output water levels in tanks, pressures in the system, and electricity used.

The method was to enter the current, as-built infrastructure into EPANET (see Figure 11), but then run the model scenario as if the water network had continuous water supply. Finally, then check if any points in the water network had inadequate water pressure, and what changes could resolve those insufficient pressures.

Along with the data about the network collected in the field, some parameters had to be approximated after returning from Peru. The elevations of junctions in the water system were found by exporting Google Earth images and surfaces into AutoCAD Civil 3D. Also it was assumed the entire network was a uniform depth below the ground surface. The water surface in the well was assumed to be 10 meters above the bottom of the well, or 40 meters below the surface elevation. Distances between points that the author did not have GPS coordinates for were estimated using the Autolength feature. 
Table 4 Summary of EPANET Inputs

\begin{tabular}{|c|c|}
\hline $\begin{array}{c}\text { Headloss } \\
\text { Formula }\end{array}$ & $\begin{array}{c}\text { Hazen- } \\
\text { Williams }\end{array}$ \\
\hline Flow Units & GPM \\
\hline Pipe Diameter & $3 \mathrm{in}$ \\
\hline Pipe Roughness & 150 \\
\hline Well Total Head & 1261.47 \\
\hline Pump Power & $20 \mathrm{hp}$ \\
\hline Tank Elevation & $1442.7 \mathrm{ft}$ \\
\hline $\begin{array}{c}\text { Tank Initial } \\
\text { Level }\end{array}$ & $0.1 \mathrm{ft}$ \\
\hline $\begin{array}{c}\text { Tank Minimum } \\
\text { Level }\end{array}$ & $0 \mathrm{ft}$ \\
\hline $\begin{array}{c}\text { Tank Maximum } \\
\text { Level }\end{array}$ & $10 \mathrm{ft}$ \\
\hline Diameter & $25.3 \mathrm{ft}$ \\
\hline
\end{tabular}

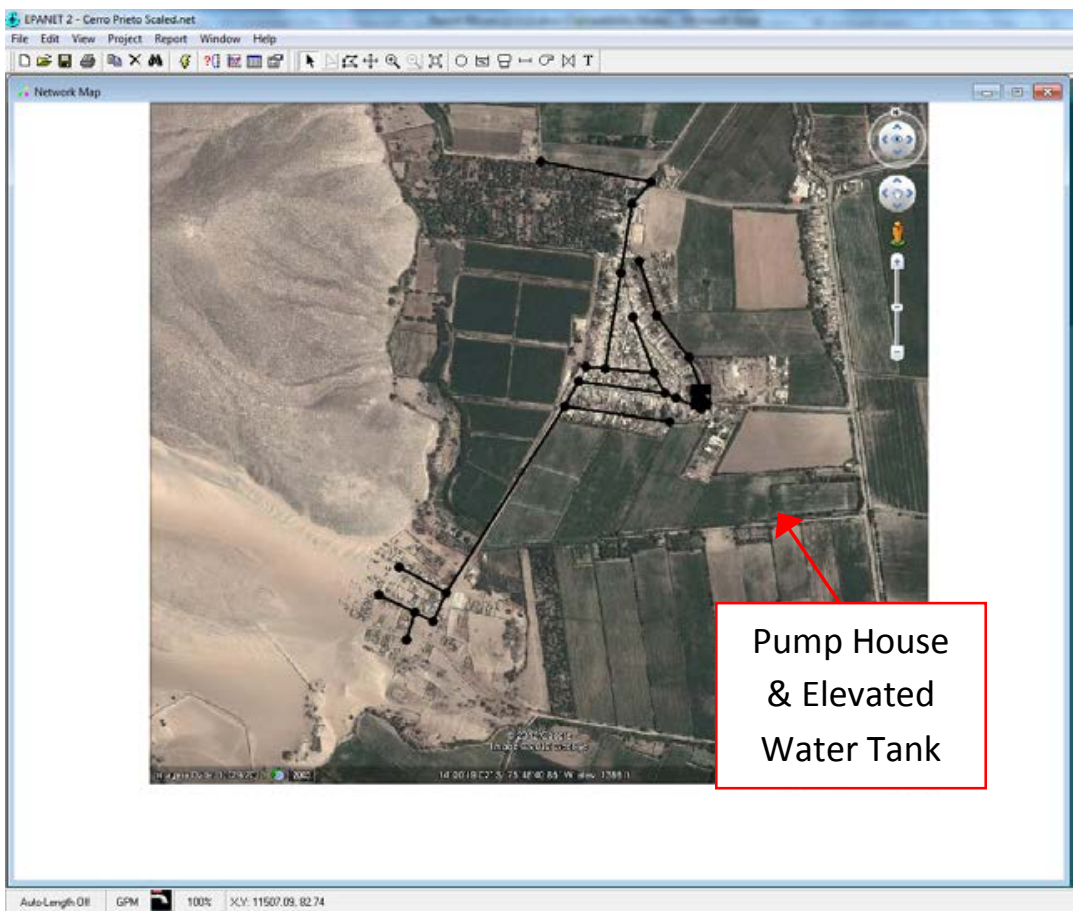

Figure 11 EPANET Model of Cerro Prieto Water Network with Aerial Image Backdrop (GoogleEarth, 2012) 
During a day, flow demand varies between maximums and minimums. In order to ensure the network can handle these short term spikes in demand, a pattern of multipliers adjusts the hourly demand based on the daily average demand. A demand multiplier of 2 means during that hour demand is twice the average demand. Over 24 hours the multipliers must average to 1 . The hourly demand multipliers for Cerro Prieto were created based on the pattern used by Fletcher McKenzie McKenzie in A Study Of Water Use And Supply In The District Of Independencia, Peru (McKenzie, 2011) and the field experience of the author. Unlike the morning/evening peak pattern common in the United States, the peak demand in Cerro Prieto is in the early afternoon (see Figure 12). Due to the hot climate, it is the custom to break for the main meal of the day, bath, and do laundry at this time of the day.

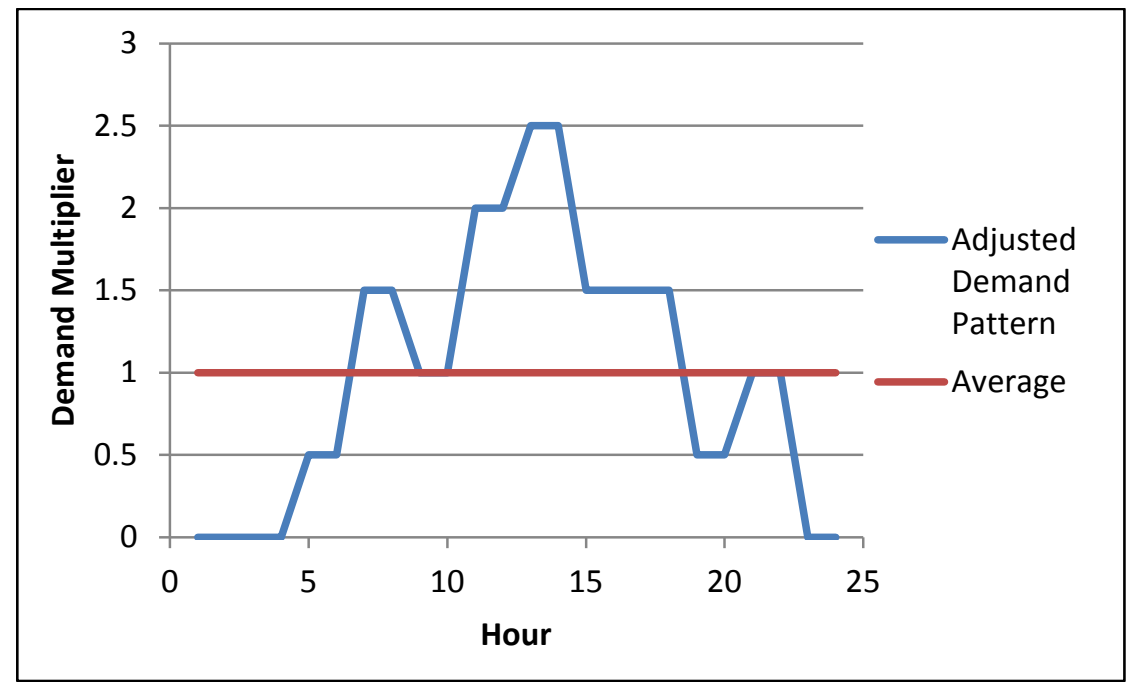

Figure 12 Adjusted Demand Pattern with Large Mid-day Peak 


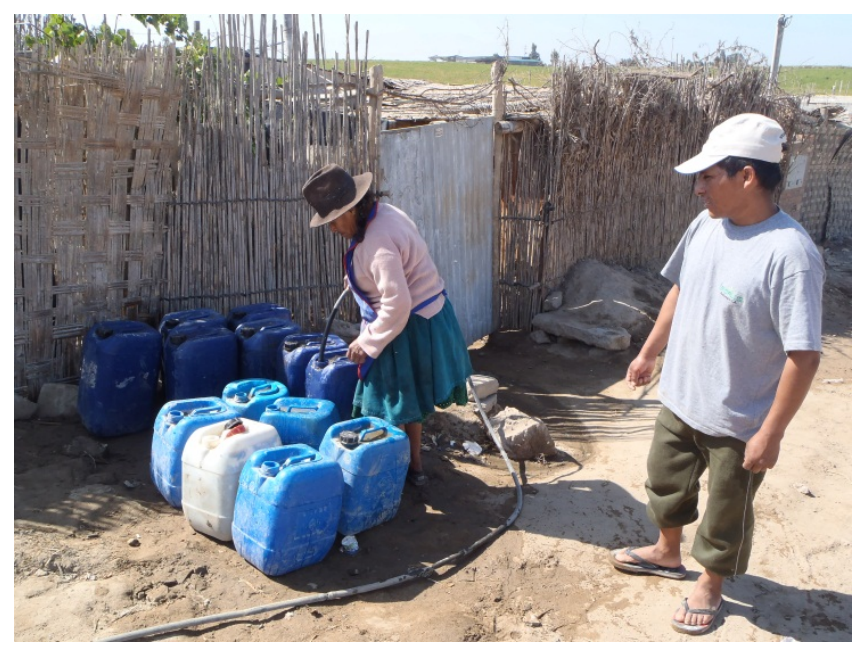

Figure 13 A Resident Stores Water in Typical Containers (O'Neill, 2012)

To approximate the demand at each node in the model, Google Earth images were examined to see how many households were served by each node. From survey results provided by EMAPA, an average number of 6 people per household, and an average volume of 464 liters of water stored per household were known. As shown in Figure 13, 20 liter rectangular storage vessels called bidones are common along with plastic tanks and barrels.

From time spent in the field, it was observed that each household on water service days typically first fill their storage containers and then complete water intensive tasks (laundry, watering grass) until their water is turned off. For this reason, it was assumed that per each water service event, an average household consumed two times their storage capacity. For a week with 3 water service events, the per capita daily water consumption was found to be 66 liters. The demand at each node was then based on the number of households it served, multiplied by the average number of residents, and the average per capita daily consumption.

\subsection{Creating a Looped Network}

In addition to providing continuous water service, the Cerro Prieto water network could be improved by adding network redundancies with a looped network pattern. Currently the network has a branched pattern, allowing only one possible route for water to reach points of use. By adding connecting pipes between branches of the network, water can bypass a pipe that has been damaged and closed for repair. A key assumption of the looped network is that important junctions have valves to isolate the damaged pipe. 
The method used to create a looped network was based on the method described by Megan Abbott in Optimization of Redundancy in Branched Water Distribution Systems (Abbott, 2012). The method allows for water network managers to determine what pipes to install first if there is not enough funding to install all of them simultaneously. It also accounts for vulnerable users in the system. Vulnerable users include anyone disproportionally affected by contaminated water. This includes young children whose development can be delayed by diarrhea inducing infections, the malnourished, or anyone with compromised immune systems such as the elderly or sick (WHO, Health topics: Diarrhoea).

To complete this analysis, the same EPANET model from Section 2.2 of this report was used. Loops were created by connecting existing nodes with a pipe. The length of the pipe was noted, and then the diameter checked to provide minimum pressures throughout the network when each link in a loop was closed. The number of users placing demands on each of the nodes, determined in the previous Section 2.2, was used to find the number of users benefitted by the new pipe.

\subsection{Results}

\subsection{Continuous Service Model}

The minimum allowable pressure was 20 psi (Chase, 2000) in order to make the analysis comparable to McKenzie's'. This is a common suggested minimum pressure in the design of water distribution networks. For each hour in the model scenario, EPANET outputs the pressure at each node, as depicted in Figure 14. For the as-built water system, a 24-hour scenario had 54 instances where a node was below the minimum pressure. Every one of these violations occurred in the area to the south west slightly separated from the center of Cerro Prieto. This area is at higher elevation than the rest of the network, and the lower pressure results match what was observed in the field. 


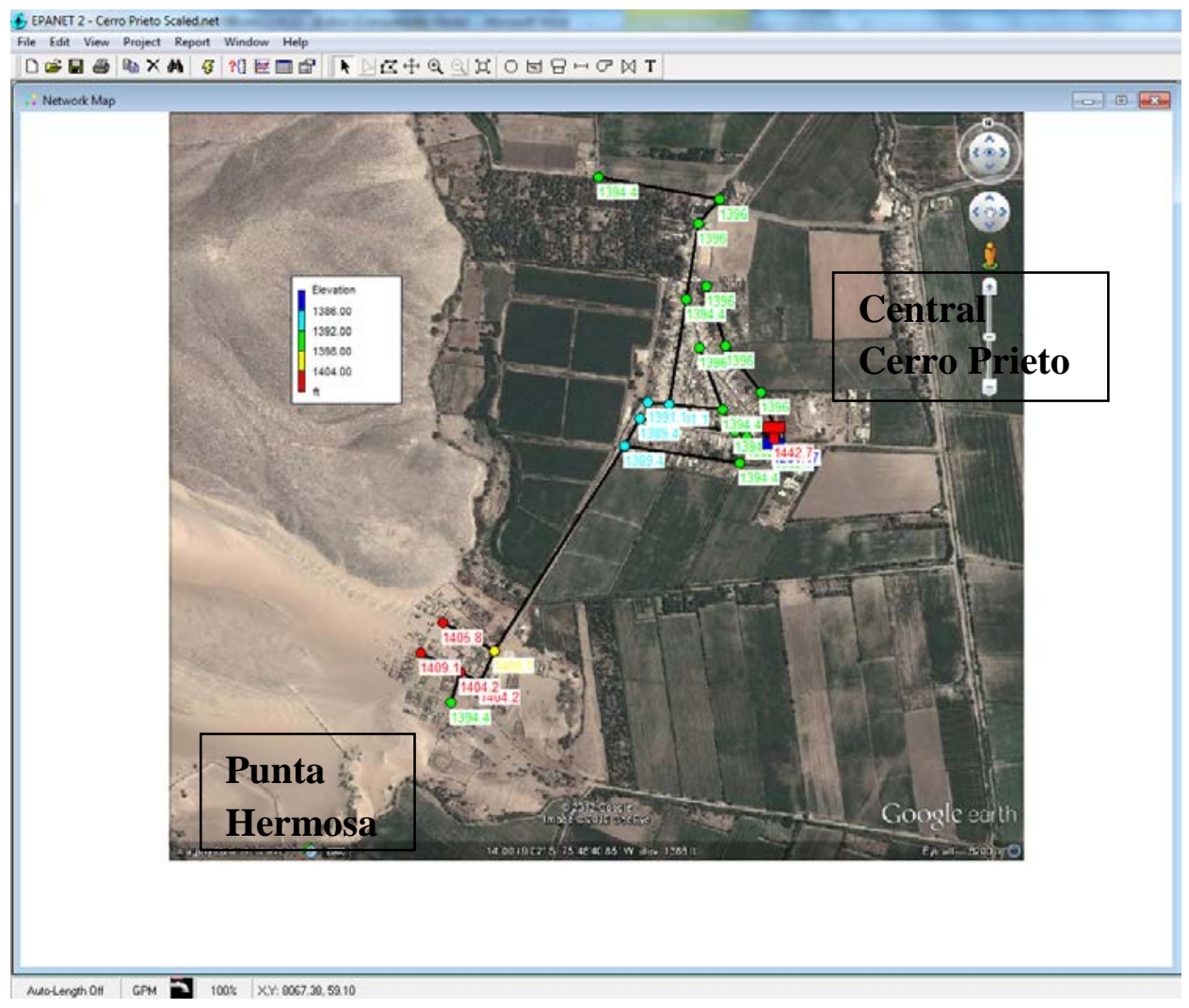

Figure 14 EPANET Model Displaying the As-Built Scenario \& Node Elevations. Points with Pressures Below 20 PSI Are All in Punta Hermosa

To reduce the number of pressure violations, various scenarios were entered and compared to the as-built scenario. These other scenarios included modifications such as increased water tower depth, increased diameter for Pipe 20 (the main line between Cerro Prieto and Punta Hermosa), increased diameter for all the pipes between the elevated water tank and Punta Hermosa, and creating a bypass of the elevated water tank. Table 5, Figure 15, and Figure 16 summarize the results of all the scenarios.

Some of the information necessary to determine the feasibility of specific scenarios was unavailable, but still included in this analysis. It is not known by the author if the elevated water tank can structurally support an increased height. Also the building costs of adding to the tank could not be reasonably estimated, along with the additional controls that would be needed to operate the pump. The cost estimates that are listed are strictly based on the cost of piping; delivery and installation are not included. 
Table 5 Summary of Model Scenarios, Pressure Violations, and Cost

\begin{tabular}{|c|c|c|c|}
\hline Model Scenario & $\begin{array}{c}\# \\
\text { Nodes } \\
<20 \\
\text { PSI } \\
\end{array}$ & $\begin{array}{c}\# \\
\text { Nodes } \\
<\mathbf{1 0} \\
\text { PSI } \\
\end{array}$ & $\begin{array}{l}\text { Cost } \\
\text { USD }\end{array}$ \\
\hline As Built & 54 & 0 & 0 \\
\hline $12 \mathrm{ft} \mathrm{Tank}$ & 40 & 0 & - \\
\hline $14 \mathrm{ft}$ Tank & 13 & 0 & - \\
\hline $16 \mathrm{ft}$ Tank & 13 & 0 & - \\
\hline 6 in Pipe 20 & 54 & 0 & $1,999.93$ \\
\hline 8 in Pipe 20 & 54 & 0 & $3,111.52$ \\
\hline 10 in Pipe 20 & 54 & 0 & $4,936.27$ \\
\hline 12 in Pipe 20 & 54 & 0 & $7,853.78$ \\
\hline 6 in Route & 31 & 0 & $3,666.54$ \\
\hline 8 in Route & 32 & 0 & $5,704.46$ \\
\hline 10 in Route & 32 & 0 & $9,049.83$ \\
\hline 12 in Route & 32 & 0 & $14,398.59$ \\
\hline $\mathrm{BP}, 4 \mathrm{ft}$ min & 77 & 0 & - \\
\hline $\mathrm{BP}, 6 \mathrm{ft}$ min & 67 & 0 & - \\
\hline $\mathrm{BP}, 8 \mathrm{ft} \min$ & 55 & 0 & - \\
\hline BP, $8 \mathrm{ft} \min \& 12 \mathrm{ft}$ Tank & 58 & 0 & - \\
\hline $\mathrm{BP}, 10 \mathrm{ft} \min \& 12 \mathrm{ft}$ Tank & 37 & 0 & - \\
\hline BP, $10 \mathrm{ft} \min \& 14 \mathrm{ft}$ Tank & 35 & 0 & - \\
\hline BP, $12 \mathrm{ft} \min \& 14 \mathrm{ft}$ Tank & 24 & 0 & - \\
\hline BP, $12 \mathrm{ft} \min \& 16 \mathrm{ft}$ Tank & 27 & 0 & - \\
\hline BP, $14 \mathrm{ft} \min \& 16 \mathrm{ft}$ Tank & 11 & 0 & - \\
\hline $\mathrm{BP}, 15 \mathrm{ft} \min \& 16 \mathrm{ft}$ Tank & 4 & 0 & - \\
\hline BP, $16 \mathrm{ft} \min \& 16 \mathrm{ft}$ Tank & 0 & 0 & - \\
\hline
\end{tabular}




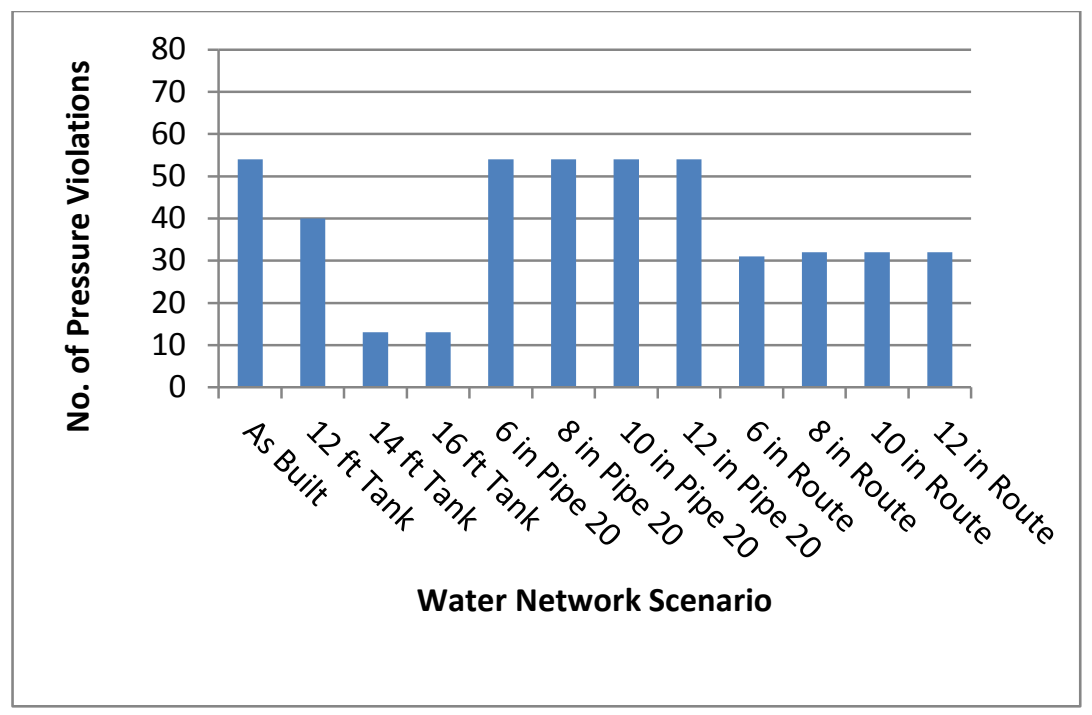

Figure 15 Number of Pressure Violations vs. Water Network Scenario

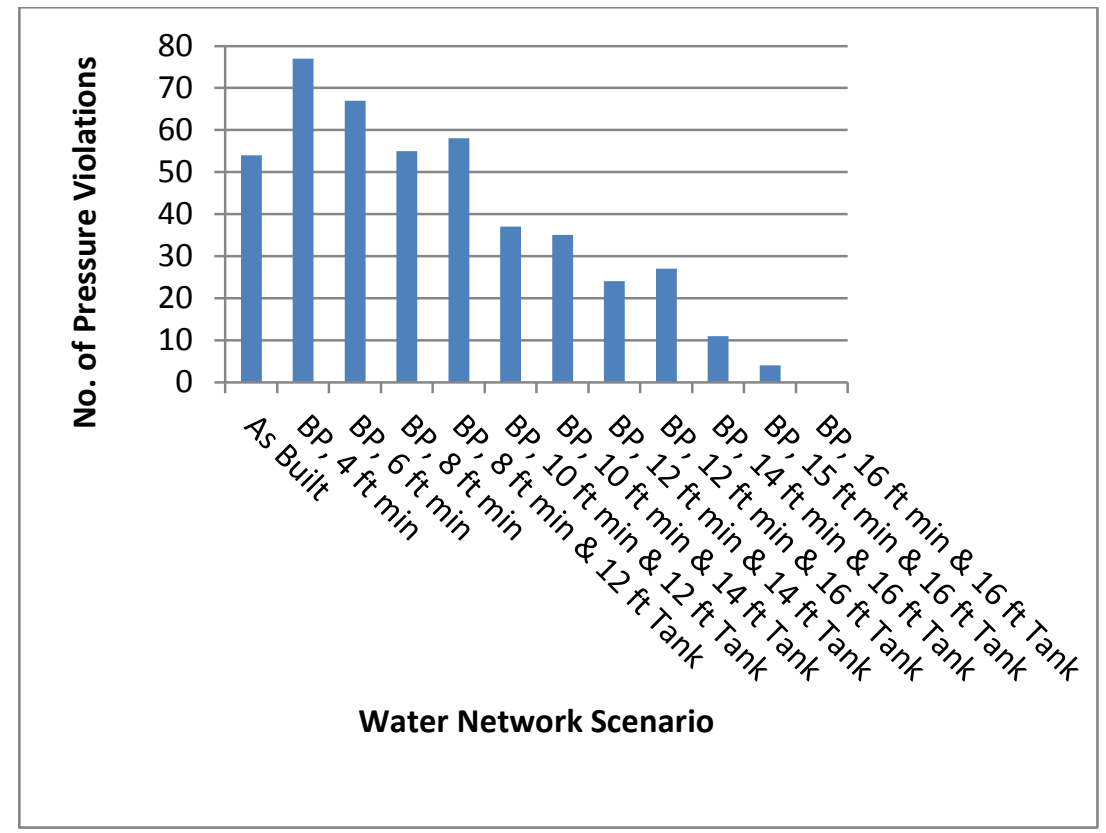

Figure 16 Number of Pressure Violations vs. Water Network Scenario with Bypass

In the as-built system, water from the well is pumped directly into the elevated water tank. From there water is feed to the network. In the bypass scenario, water from the well is pumped directly into the network and the elevated water tank is filled or drained during maximum and minimum demand periods (see Figure 17). To prevent 
excessive pressures in the system, a rule-based control was added to the EPANET model. The control specified when the pump was to turn on based on the water level in the elevated water tank (see Figure 18). The only scenario that had zero pressure violations requires the tank walls be heightened from 10 to 16 feet (measured from the bottom of the storage compartment) and the pump to be operating whenever the water level fell below 16 feet (whenever the tank was not completely full).

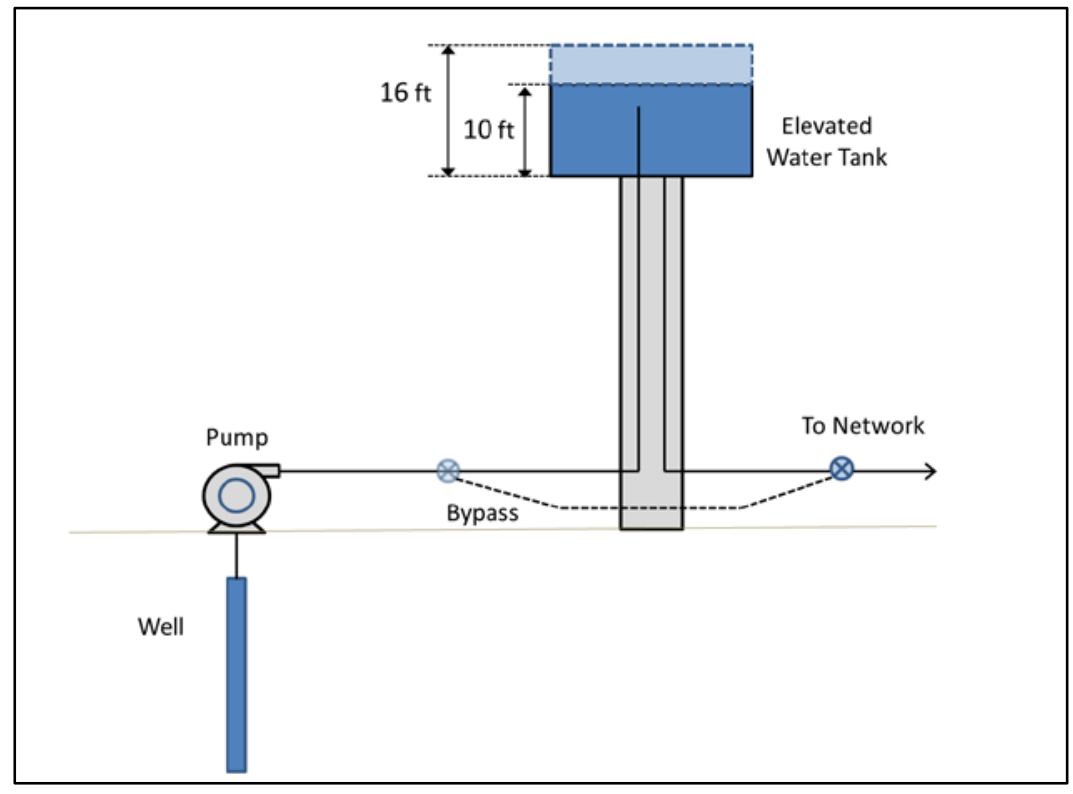

Figure 17 Diagram of Well-Pump-Tank Setup with Bypass Piping and Increased Tank Height

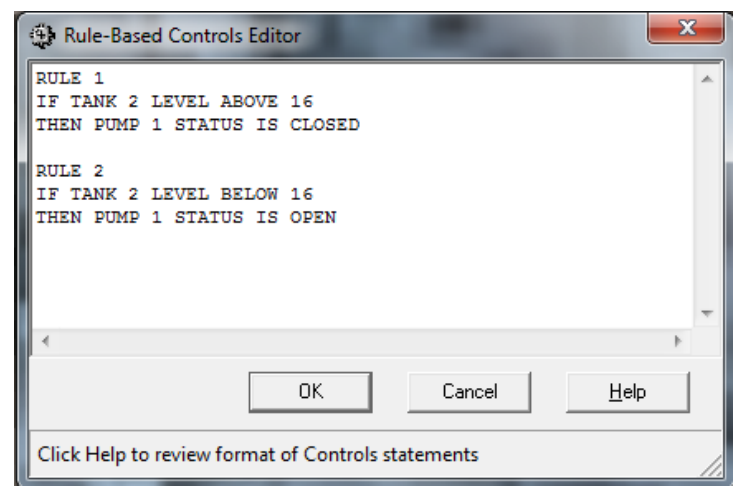

Figure 18 Screenshot of EPANET Rule Based Control for Pump Operation and Tank Water Level 


\subsection{Looped Network Model}

The looped network analysis in Abbott's report was based on all points in the network staying above a minimum pressure of 3 meters of head (about $4.258 \mathrm{psi}$ ). In the previous section it was found the as-built system had 54 pressure violations during a day, and those pressure violations were based on a minimum of 20 psi. For this case, the pipe diameters were sized based on a minimum pressure of 20 psi and holding the number of violations to no more than 54 (the number of as-built violations).

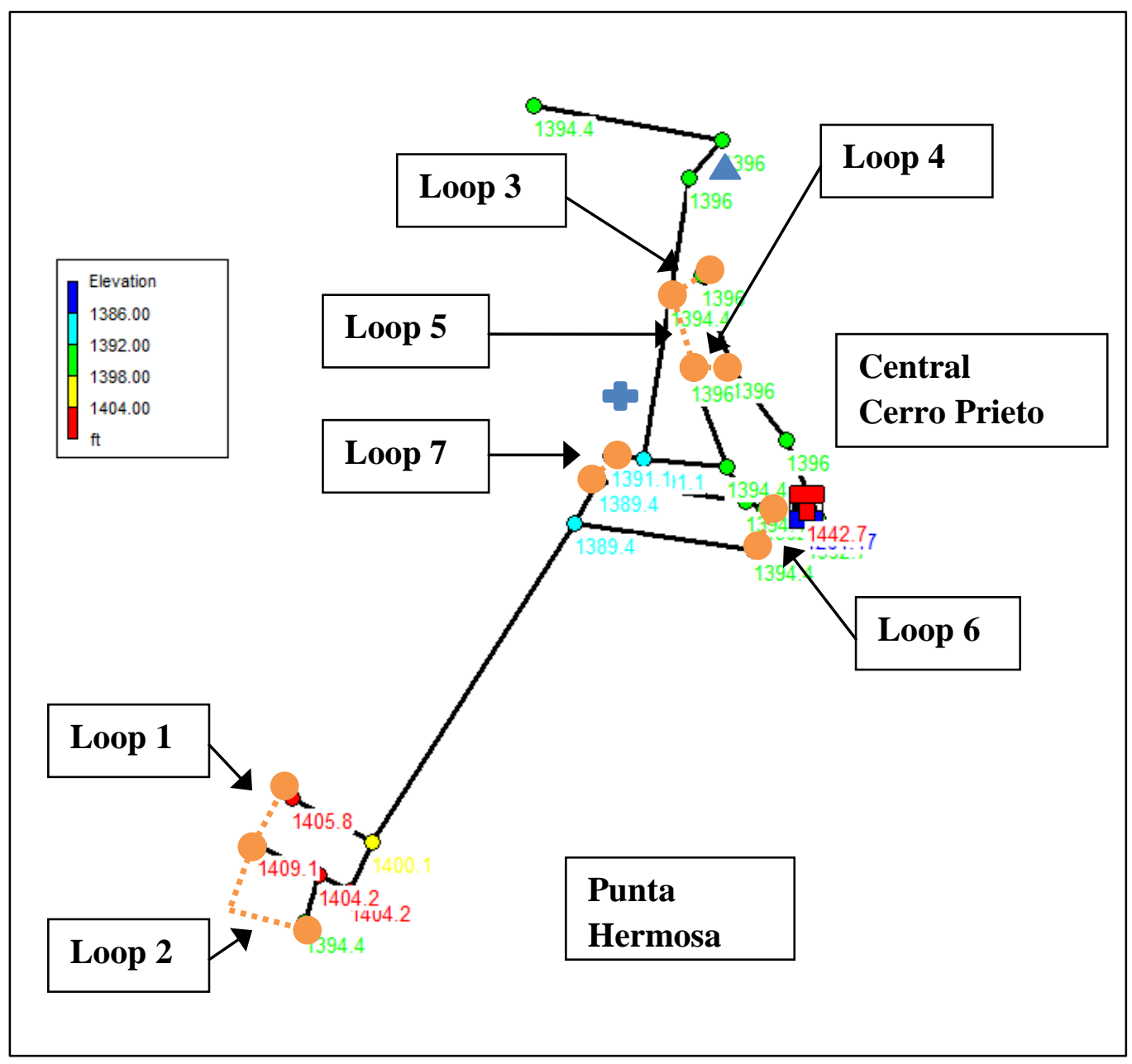

Figure 19 Proposed Loop Connections. The Health Clinic and School Are Marked with a Cross and Triangle respectively 
The number of users benefiting was found by summing all the users in the newly created loop, as well as users downstream who may be able to still receive water in case of a pipe closure due to the new pipe. It was assumed that vulnerable users (children, elderly, sick) were evenly distributed throughout the network. As found by Abbott, an even distribution of vulnerable users will not change the User-to-Dollar ratio, and so the priority rankings of the loops do not change. However, there are some instances where vulnerable users concentrate in one place.

In Cerro Prieto there is a combined pre-school and primary school, and also a health clinic (see Figure 19). Based on statistics from the 2007 Peruvian census, in the district of Salas Guadalupe about $20 \%$ of the population is of school age. The number of vulnerable users located at the school was thus estimated to be $20 \%$ of the total number of users in the network (about 560 children). The health clinic in Cerro Prieto has a small pharmacy and is equipped to handle only simple treatments (first-aid, vaccinations). To consult a doctor, do any lab work, or see the obstetrician, residents must go to the health clinic in nearby central Guadalupe. For this reason it was estimated that on the average day about 50 people would be at the clinic.

Table 6 Summary of Loop Analysis (*No Feasible Solution)

\begin{tabular}{|c|c|c|c|c|}
\hline $\begin{array}{c}\text { Loop } \\
\text { Number }\end{array}$ & $\begin{array}{c}\text { New Pipe length } \\
\text { (ft) }\end{array}$ & $\begin{array}{c}\text { Total Pipe Length } \\
\text { to be Added or } \\
\text { Replaced (ft) }\end{array}$ & $\begin{array}{c}\text { Pipe } \\
\text { Diameter } \\
\text { (in) }\end{array}$ & $\begin{array}{c}\text { Cost (USD) } \\
\text { (PlazaConstructor) }\end{array}$ \\
\hline 1 & 330 & 330 & 3 & 118.03 \\
\hline 2 & 660 & 660 & 3 & 236.06 \\
\hline $3^{*}$ & 150 & - & - & - \\
\hline $4^{*}$ & 150 & - & - & - \\
\hline 5 & 500 & 500 & 3 & 180.52 \\
\hline 6 & 100 & 1970 & 4 & $1,457.38$ \\
\hline 7 & 100 & 770 & 4 & 582.95 \\
& & 1970 & 6 & $1,457.38$ \\
& & & & $2,040.34$ \\
\hline
\end{tabular}

Due to the unique triangular-branched configuration of Cerro Prieto, and the higher elevation of the neighborhood of Punta Hermosa to the southwest, only 3 of the proposed loops could be completed without replacing any other pipes in the network (see Table 6). Loops 6 and 7 both required increasing the diameter of the pipes leading to Punta Hermosa in order to maintain original pressure levels. Loops 3 and 4 have no simple solution that could maintain existing pressure levels. Generally the problem is the scenario when one of the pipes on the loop and near the elevated water tank is closed. This then forces all the flow needed for Punta Hermosa to first take a long and convoluted path around central Cerro Prieto, which causes high energy losses. It is 
possible closing Loops 3 or 4 should be accompanied by closing Loop 6 to maintain the pressure status quo.

Table 7 Ranking of Loops Based on Total User Benefited Per Dollar Method (*No Feasible Solution)

\begin{tabular}{|c|c|c|c|c|}
\hline Rank & Loop Number & Total Users Benefiting & Cost (USD) & Users/USD \\
\hline 1 & 5 & 1008 & 180.52 & 5.58 \\
\hline 2 & 1 & 468 & 118.03 & 3.97 \\
\hline 3 & 6 & 2286 & $1,457.38$ & 1.57 \\
\hline 4 & 2 & 288 & 236.06 & 1.22 \\
\hline 5 & 7 & 2286 & $2,040.34$ & 1.12 \\
\hline 6 & $3^{*}$ & - & - & - \\
\hline 7 & $4 *$ & - & - & - \\
\hline
\end{tabular}

Based on the Users Benefitted to U.S. Dollar ratio, Loop 5 should be given first priority, followed by Loop 1(see Table 7). Loops 3 and 4 have no final benefit-cost ratio because of the need for many additional pipe replacements which was deemed unfeasible. When considering the Vulnerable Users Benefitted to U.S. Dollar ratio, again Loop 5 has the best value (see Table 8). Loop 1 does not benefit any vulnerable users, and so falls from the $2^{\text {nd }}$ ranking for vulnerable users. Loops 1 and 2 have zero vulnerable users benefitted, and so are excluded from the vulnerable users benefitted per dollar ranking in Table 6.

Table 8 Ranking of Loops for Each Vulnerable User Facility using Vulnerable User Benefitted Per Dollar Method, Loops Benefitting Zero Vulnerable Users are Excluded (*No Feasible Solution)

\begin{tabular}{|c|c|c|c|}
\hline Rank & No Vulnerable Facilities & Health Clinic & School \\
\hline 1 & 5 & 5 & 5 \\
\hline 2 & 1 & 6 & 6 \\
\hline 3 & 6 & 7 & 7 \\
\hline 4 & 2 & - & - \\
\hline 5 & 7 & - & - \\
\hline 6 & $3^{*}$ & - & - \\
\hline 7 & $4^{*}$ & - & - \\
\hline
\end{tabular}


In order to see how much Loop 6 would need to be weighted in order to overtake Loop 1 in rankings, the weighting method proposed by Abbott was used (Abbott, 2012). To weight vulnerable users benefited versus total user benefited, each was multiplied by its respective percentage listed in Table 9. This was then divided by the cost for the loop to find the users benefitted to cost ratio. From Table 9, in order for Loop 6 to rank higher than Loop 1 (which has zero vulnerable users benefitting) a weighting of 90\%/10\% must be applied.

Table 9 Ranking of Loops with Weighting of Vulnerable \& Total Users Benefiting Per Dollar

\begin{tabular}{|c|c|c|c|c|c|c|}
\hline Rank & $\mathbf{5 0 \% / 5 0 \%}$ & $\mathbf{6 0} \% \mathbf{/ 4 0} \%$ & $\mathbf{7 0} \mathbf{0} / \mathbf{3 0} \%$ & $\mathbf{8 0} \% \mathbf{2 0} \%$ & $\mathbf{9 0 \% / 1 0 \%}$ & $\mathbf{1 0 0 \%}$ \\
\hline 1 & 5 & 5 & 5 & 5 & 5 & 5 \\
\hline 2 & 1 & 1 & 1 & 1 & 6 & 6 \\
\hline 3 & 6 & 6 & 6 & 6 & 1 & 7 \\
\hline 4 & 7 & 7 & 7 & 7 & 7 & - \\
\hline 5 & 2 & 2 & 2 & 2 & 2 & - \\
\hline 6 & - & - & - & - & - & - \\
\hline 7 & - & - & - & - & - & - \\
\hline
\end{tabular}

It was expected that loops that are located generally upstream in the network would have the greatest priority (Abbott, 2012). However in the case of Cerro Prieto, some of the upstream loops required expensive replacement of other pipes. Even though these loops benefited a large number of users, their high cost lowered their users benefited to cost ratio.

\subsection{Discussion}

The Cerro Prieto network, as it is built now, is physically capable of supplying continuous water service. There are a number of nodes where the pressure falls below the design goal minimum of 20 psi, however, none ever fall below 10 psi. At the time of data collection in the field, it was unclear if the design of the network was insufficient, and determining that was one of the goals of this report. The service provided by the water network could be greatly improved simply by changing the method of operation.

Of the list of possible improvements, it is clear that closing a loop generally costs less than the attempts to increase pressure by upgrading current aspects. Creating redundancies in the network is especially valuable for a network located in a seismically 
active region. Operators must take the time to rank possible loops based on benefit and cost before beginning. In Cerro Prieto some of the more upstream loops, which benefited a large number of people, also were very expensive due to the number of additional pipes that would need to be replaced. Loops 3 and 4 did not even have a reasonable solution without replacing more than half the pipes in the network. Other less quantifiable factors should be considered when prioritizing loops, such as disruption to properties, benefitting natural congregation centers after an earthquake and users who are sometimes marginalized.

Some of the scenarios discussed to improve pressure in the network could have some negative consequences. The construction necessary to replace piping with larger diameter piping, might cause a long cutoff of service. Another concern is if the elevated water tank is bypassed, the water will no longer have any detention time before entering the network. There are demand points in the network immediately by the well and pump, and any chlorine added for disinfection may not have sufficient time to become effective.

It appears that the largest barrier to providing continuous water service is concern for water conservation. Users in the network pay a flat monthly fee for water service and there are no installed water meters. It was noted during field work that many water officials equate increased water access with increased water waste. There seems to be a common belief that the users cannot be trusted to use increased water access responsibly. Due to the structure of EMAPA's operation and management decisions are made in a topdown manner. The typical users have little opportunity for input.

However many users currently waste large amounts of water due to the intermittent system. Due to the irregularity of water service, there is an incentive to store as much water as possible. However during each water service event, the unused stored water is wasted in exchange for fresher water. While there were examples of some abusing their water service (taps left open, irrigate gardens, etc.), it may not continue if a water responsibility campaign or meters were adopted.

\subsection{Future Work}

Although the as-built and as-operated water system is inconvenient, the per capita water consumption does meet the minimum World Health Organization definition of 20 liters as access to sufficient quantity of water (Health Through Safe Drinking Water and Basic Sanitation). However, by changing the operation of the as-built system to continuous, the well may be placed under greater demands per time period. The most important additional information needed is how much water the well can really provide. All the scenarios discussed previously in this report assumed the well could supply all demands. All too often, projects such as this case study focus on the extraction of water, and neglect management of the water resource (Ennis-McMillan, 2006). 
This well in Cerro Prieto draws from the Ica Aquifer. Due to the agricultural boom in the Ica area, this aquifer has recently begun to be over-drafted (see Figure 20). Wells using the aquifer have seen the water table drop from 0.5 to 2 meters per year (Postigo, 2012). A drawdown and recharge study should be conducted for the well in Cerro Prieto as well as a long term estimate to ensure that the well does not go dry.

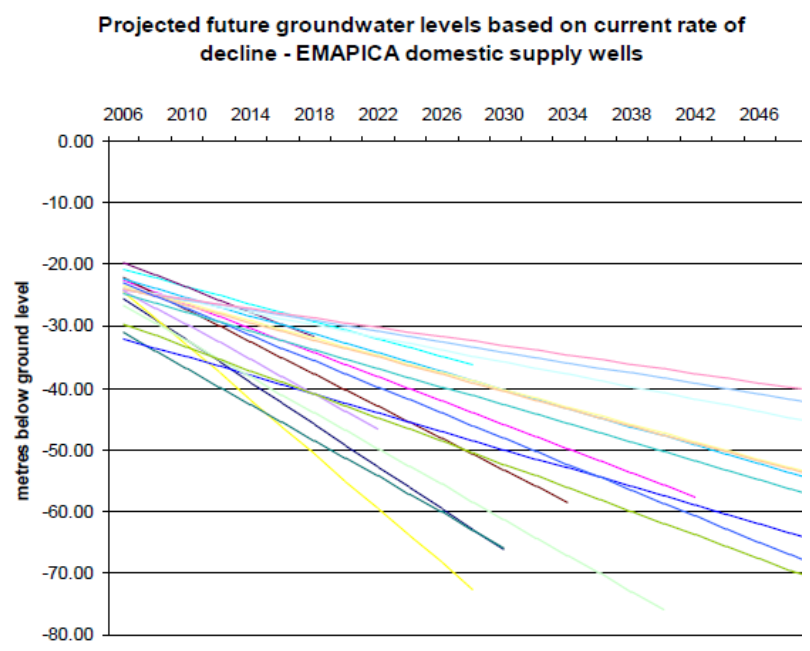

Figure 20 Estimated Future Groundwater Levels (Postigo, 2012)

\subsection{Conclusions}

The quality of service provided by the Cerro Prieto water network could be greatly improved by operating the system continuously. This change would greatly increase ease of use and convenience. It is also possible to provide increased pressures with the addition of 6 feet to the height of the elevated water tank and a bypass pipe.

The health of the community would likely improve because routes of contamination associated with pipe infiltration and stored water would be eliminated. A prerequisite to changing the operation method is a drawdown study of the well to determine what it can feasibly provide. At a minimum a water conservation campaign should coincide with change in operation. EMAPA Salas should also consider a pilot study of water meters.

Finally, adding redundancies in the water network are a simple upgrade with large benefits. Just a few short loop connections would benefit the majority of Cerro Prieto, but care must be taken in selecting which. 


\section{References}

(n.d.). Retrieved 12 5, 2012, from PlazaConstructor:

http://www.google.com/url?sa=t\&rct=j\&q=\&esrc=s\&source=web\&cd=10\&ved=0CHwQF jAJ\&url=http\%3A\%2F\%2Fwww.plazaconstructor.com\%2Fperuconstruye\%2Fuploads\%2F costos\%2Flista.xls\&ei=yAS5UKOpCsW72QXooGoAw\&usg=AFQjCNHSe_iFVuB65GhUNuYAghX2rbKmlg

Magnitude 8.0 - NEAR THE COAST OF CENTRAL PERU. (2007, 8 15). Retrieved 12 5, 2012, from USGS Significant Earthquake and News Headlines Archive: http://earthquake.usgs.gov/earthquakes/eqinthenews/2007/us2007gbcv/

USAID Assists Peru After Devastating Earthquake. (2007, 9 14). Retrieved 12 5, 2012, from USAID:

http://transition.usaid.gov/locations/latin_america_caribbean/perueq/index.html

Very strong dangerous earthquake near Ica, Peru. $(2012,23)$. Retrieved 125 , 2012, from Earthquake-Report: http://earthquake-report.com/2012/01/30/very-strong-shallowdangerous-earthquake-near-ica-peru/

Abbott, M. (2012). Optimization of Redundancy in Branched Water Distribution Sytems. Houghton, Michigan USA: Michigan Technological University.

Censos Nacionales 2007 Perú. (n.d.). Retrieved 12 5, 2012, from El Instituto Nacional de Estadística e Informática (INEI) Perú:

http://desa.inei.gob.pe/censos2007/tabulados/?id=ResultadosCensales

Chary, S. (2009). The Cost of Coping with Intermittent Water Supply in India. Global Water Intelligence.

Chase, D. V. (2000). Operation of Water Distribution Systems. New York: McGraw-Hill, Inc.

CIA World Factbook - South America - Peru. (n.d.). Retrieved 12 5, 2012, from CIA World Factbook: https://www.cia.gov/library/publications/the-world-factbook/geos/pe.html EMAPASalas. (2012). Analisis de Calidad del Agua de Pozo.

EMAPASalas. (2012). Diagnóstico. 
Ennis-McMillan, M. C. (2006). A Precious Liquid: Drinking Water and Culture in the Valley of Mexico. Belmont, CA: Thomson Higher Education.

EPANET. (n.d.). Retrieved 12 5, 2012, from USEPA:

http://www.epa.gov/nrmrl/wswrd/dw/epanet.html

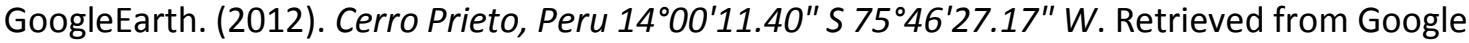
Earth: http://www.google.com/earth/index.html

Guadalupe, M. S. (2012). Salas Completo.

Health Through Safe Drinking Water and Basic Sanitation. (n.d.). Retrieved 12 5, 2012, from World Health Organization:

http://www.who.int/water_sanitation_health/mdg1/en/index.html

Ica Weather, Peru Weather Averages. (n.d.). Retrieved 12 5, 2012, from World Weather Online: http://www.worldweatheronline.com/Ica-weather-averages/Ica/PE.aspx

McIntosh, A. (2003). Asian Water Supplies. Reaching the Urban Poor. London, UK: Asian Development Bank.

McKenzie, F. (2011). A Study of Water Use and Supply in the District of Independencia, Peru. Houghton, Michigan USA: Michigan Technological University.

O'Neill, J. (2012, 6 7). Cerro Prieto, Salas Guadalupe, Ica, Peru.

Pandit, F. F. (n.d.). Intermittent Water Distribution. Retrieved 12 17, 2012, from Sustainable Sanitation and Water Management : http://www.sswm.info/category/implementationtools/water-distribution/hardware/water-distribution-networks/intermittent-w

Pojman, A. (2006). Water Works: Capacity and Communication for Social Change in Peruvian Municipalities. Ontario, Canada: University of Guelph.

Postigo, J. C. (2012, 5). Green Week 2012. Retrieved 12 5, 2012, from European Commission: http://ec.europa.eu/environment/greenweek/sites/default/files/2-9_postigo.pdf

Schmall, E. (2010, 9 9). Peru water wars threaten agricultural export boom. Retrieved 12 5, 2012, from Reuters: http://www.reuters.com/article/2010/09/09/us-peru-water-featureidUSTRE6885QF20100909

WHO. (n.d.). 18. Conservation of water in public and domestic supply systems. Retrieved 1214 , 2012, from WHO Water Supply, Sanitation and Hygiene Development: http://www.who.int/water_sanitation_health/hygiene/plumbing18.pdf 
WHO. $(2008,5)$. Guidelines on Management Options for Empty Pesticide Containers. Retrieved 12 4, 2012, from WHO:

http://www.who.int/whopes/recommendations/Management_options_empty_pesticid e_containers.pdf

WHO. (n.d.). Health topics: Diarrhoea. Retrieved 12 17, 2012, from WHO: http://www.who.int/topics/diarrhoea/en/ 


\section{Appendix A Handheld GPS Data}

\begin{tabular}{|c|c|c|c|}
\hline Mark & Description & $\begin{array}{llllllllllll}\circ & 0^{\prime} & 0^{\prime \prime}\end{array}$ & $0^{\circ} 0^{\prime} 0^{\prime \prime}$ \\
\hline 466 & Pump & S 140016.6 & WO 754629.4 \\
\hline 467 & Reservoir Floor & S 140016.3 & WO 754628.5 \\
\hline 469 & Top of Reservoir & S 140016.3 & WO 754629.3 \\
\hline 470 & Desague Junction Leaving & S 140016.1 & WO 754629.0 \\
\hline 471 & Junction Leaving/Exposed Valve & S 140016.7 & WO 754628.8 \\
\hline 472 & Valve \#2 & S 140016.2 & WO 754630.9 \\
\hline 473 & Valve \#3 & S 140015.1 & WO 754632.1 \\
\hline 474 & Valve \#4 & S 140014.6 & WO 754637.9 \\
\hline 475 & Valve \#5, west side in font of football field & S 140028.6 & WO 754647.7 \\
\hline 476 & Valve \#6, NE corner of plaza & S 140031.4 & WO 754649.4 \\
\hline 477 & Valve \#7, 1 block west of plaza & S 140029.1 & WO 754653.1 \\
\hline 478 & Valve \#8, 1 block NW of plaza & S 140027.1 & WO 754651.5 \\
\hline 479 & Valve \#9, down street & S 140010.4 & WO 754631.7 \\
\hline
\end{tabular}




\section{Appendix B Pipe Data}

\begin{tabular}{|c|c|c|c|c|}
\hline \multicolumn{5}{|c|}{$\begin{array}{c}\text { Lista de Precios de Materiales de Construccion } \\
\text { (Construction Material Price List) } \\
\text { TC S/.2.96 }\end{array}$} \\
\hline Business & Product & $\begin{array}{l}\text { Price } \\
\text { USD }\end{array}$ & in & $\begin{array}{l}\text { Pipe } \\
\text { Diameter } \\
\text { Approx. } \\
\text { (in) }\end{array}$ \\
\hline $\begin{array}{l}\text { NICOLL } \\
\text { PERU S.A. }\end{array}$ & $\begin{array}{l}\text { TUBO PVC AGUA U.F CLASE 7.5, ISO } \\
4422 \text { DN 63mm x 6m }\end{array}$ & 4.92 & 2.48 & \\
\hline $\begin{array}{r}\text { NICOLL } \\
\text { PERU S.A. }\end{array}$ & $\begin{array}{l}\text { TUBO PVC AGUA U.F CLASE 7.5, ISO } \\
4422 \text { DN } 75 \mathrm{~mm} \times 6 \mathrm{~m}\end{array}$ & 6.94 & 2.95 & 3 \\
\hline $\begin{array}{l}\text { NICOLL } \\
\text { PERU S.A. }\end{array}$ & $\begin{array}{l}\text { TUBO PVC AGUA U.F CLASE 7.5, ISO } \\
4422 \text { DN 90mm x 6m }\end{array}$ & 9.86 & 3.54 & \\
\hline $\begin{array}{l}\text { NICOLL } \\
\text { PERU S.A. }\end{array}$ & $\begin{array}{l}\text { TUBO PVC AGUA U.F CLASE 7.5, ISO } \\
4422 \text { DN } 110 \mathrm{~mm} \times 6 \mathrm{~m}\end{array}$ & 14.57 & 4.33 & 4 \\
\hline $\begin{array}{l}\text { NICOLL } \\
\text { PERU S.A. }\end{array}$ & $\begin{array}{l}\text { TUBO PVC AGUA U.F CLASE 7.5, ISO } \\
4422 \mathrm{DN} 140 \mathrm{~mm} \times 6 \mathrm{~m}\end{array}$ & 23.57 & 5.51 & \\
\hline $\begin{array}{l}\text { NICOLL } \\
\text { PERU S.A. }\end{array}$ & $\begin{array}{l}\text { TUBO PVC AGUA U.F CLASE 7.5, ISO } \\
4422 \text { DN } 160 \mathrm{~mm} \times 6 \mathrm{~m}\end{array}$ & 30.30 & 6.29 & 6 \\
\hline $\begin{array}{l}\text { NICOLL } \\
\text { PERU S.A. }\end{array}$ & $\begin{array}{l}\text { TUBO PVC AGUA U.F CLASE 7.5, ISO } \\
4422 \text { DN } 200 \mathrm{~mm} \times 6 \mathrm{~m}\end{array}$ & 47.14 & 7.87 & 8 \\
\hline $\begin{array}{l}\text { NICOLL } \\
\text { PERU S.A. }\end{array}$ & $\begin{array}{l}\text { TUBO PVC AGUA U.F CLASE 7.5, ISO } \\
4422 \text { DN } 250 \mathrm{~mm} \times 6 \mathrm{~m}\end{array}$ & 74.79 & 9.84 & 10 \\
\hline $\begin{array}{l}\text { NICOLL } \\
\text { PERU S.A. }\end{array}$ & $\begin{array}{l}\text { TUBO PVC AGUA U.F CLASE 7.5, ISO } \\
4422 \text { DN 315mm x 6m }\end{array}$ & 119.00 & 12.40 & 12 \\
\hline $\begin{array}{l}\text { NICOLL } \\
\text { PERU S.A. }\end{array}$ & $\begin{array}{l}\text { TUBO PVC AGUA U.F CLASE 7.5, ISO } \\
4422 \text { DN 355mm x } 6 \mathrm{~m}\end{array}$ & 150.13 & 13.97 & \\
\hline $\begin{array}{l}\text { NICOLL } \\
\text { PERU S.A. }\end{array}$ & $\begin{array}{l}\text { TUBO PVC AGUA U.F CLASE 7.5, ISO } \\
4422 \mathrm{DN} 400 \mathrm{~mm} \times 6 \mathrm{~m}\end{array}$ & 190.54 & 15.74 & \\
\hline
\end{tabular}




\section{Appendix C Water Consumption}

\begin{tabular}{|c|c|c|c|c|c|c|}
\hline $\begin{array}{c}\text { ¿Cuántas } \\
\text { personas? } \\
\text { (How } \\
\text { Many } \\
\text { People?) }\end{array}$ & $\begin{array}{l}\text { ¿Cuantos días } \\
\text { a la semana? } \\
\text { (How Many } \\
\text { Days of the } \\
\text { Week?) }\end{array}$ & $\begin{array}{l}\text { ¿Almacena } \\
\text { el agua? } \\
\text { (Do You } \\
\text { Store } \\
\text { Water?) }\end{array}$ & $\begin{array}{c}\text {.Si, } \\
\text { ¿Cómo? } \\
\text { (Yes, } \\
\text { How?) }\end{array}$ & $\begin{array}{l}\text { Bidones } \\
\text { (Small } \\
\text { Vessels) }\end{array}$ & $\begin{array}{l}\text { Cilindro- } \\
\text { Barril } \\
\text { (Cylinders - } \\
\text { Barrels) }\end{array}$ & $\begin{array}{l}\text { Litros } \\
\text { Totales } \\
\text { (Total } \\
\text { Liters) }\end{array}$ \\
\hline 5 & 3 & Si (Ys) & & & $\mathrm{X}$ & 70 \\
\hline 4 & 3 & Si (Yes) & $\begin{array}{l}\text { BALDES } \\
\text { (Buckets) }\end{array}$ & & & 90 \\
\hline 3 & 3 & Si (Yes) & $\begin{array}{l}\text { BALDES } \\
\text { (Buckets) }\end{array}$ & $\mathrm{X}$ & $\mathrm{X}$ & 90 \\
\hline 5 & 3 & Si (Yes) & & & $\mathrm{X}$ & 200 \\
\hline 7 & 3 & Si (Yes) & & & $\mathrm{X}$ & 200 \\
\hline 4 & 3 & Si (Yes) & & & & \\
\hline 2 & 3 & $\mathrm{Si}$ (Yes) & & & $\mathrm{X}$ & 40 \\
\hline 11 & 3 & Si (Yes) & & & $X$ & 70 \\
\hline 6 & 3 & Si (Yes) & & & $\mathrm{X}$ & 200 \\
\hline 2 & 3 & Si (Yes) & & & 400 & 400 \\
\hline 7 & 3 & Si (Yes) & $\begin{array}{c}\text { TANQUE } \\
\text { (Tank) }\end{array}$ & $\mathrm{X}$ & & 2500 \\
\hline 6 & 3 & Si (Yes) & $\begin{array}{c}\text { TANQUE } \\
\text { (Tank) }\end{array}$ & & $\mathrm{X}$ & 2500 \\
\hline 4 & 3 & Si (Ys) & & & $\mathrm{X}$ & 200 \\
\hline 6 & 3 & Si (Yes) & & & $\mathrm{X}$ & 200 \\
\hline 6 & 3 & Si (Yes) & & $\mathrm{X}$ & & \\
\hline 5 & 3 & Si (Yes) & & & $\mathrm{X}$ & 200 \\
\hline 6 & 3 & Si (Yes) & & & $\mathrm{X}$ & 80 \\
\hline 3 & 3 & Si (Yes) & & & $\mathrm{X}$ & 80 \\
\hline 6 & 3 & Si (Yes) & & $\mathrm{X}$ & & 35 \\
\hline 4 & 3 & Si (Yes) & $\begin{array}{l}\text { BALDES } \\
\text { (Buckets) }\end{array}$ & $\mathrm{X}$ & & 50 \\
\hline 6 & 3 & Si (Yes) & & & $\mathrm{X}$ & 200 \\
\hline 5 & 3 & Si (Yes) & & & $\mathrm{X}$ & 200 \\
\hline 6 & 3 & Si (Yes) & & $\mathrm{X}$ & & \\
\hline 3 & 3 & Si (Yes) & & & 1200 & 1200 \\
\hline 6 & 3 & Si (Yes) & & 120 & 400 & 520 \\
\hline 6 & 3 & Si (Yes) & & $\mathrm{X}$ & & 70 \\
\hline
\end{tabular}




\begin{tabular}{|c|c|c|c|c|c|c|}
\hline 10 & 3 & Si (Yes) & & & $\mathrm{X}$ & 200 \\
\hline 6 & 3 & Si (Yes) & & & & 0 \\
\hline 6 & 3 & Si (Yes) & & & 600 & 600 \\
\hline 3 & 3 & Si (Yes) & Si (Yes) & 3 & 5 & 1600 \\
\hline 6 & 2 & Si (Yes) & & 120 & 1200 & 1320 \\
\hline 4 & & & & & & \\
\hline 6 & 3 & Si (Yes) & & 200 & 200 & 400 \\
\hline 4 & 3 & Si (Yes) & & & $\mathrm{X}$ & 200 \\
\hline 6 & 3 & Si (Yes) & & 120 & 400 & 520 \\
\hline 6 & 3 & Si (Yes) & & $\mathrm{X}$ & $\mathrm{X}$ & 250 \\
\hline 5 & 3 & $\mathrm{Si}$ (Yes) & & & 1200 & 1200 \\
\hline 6 & & & & & & \\
\hline 6 & 3 & Si (Yes) & & & 400 & 400 \\
\hline $\begin{array}{l}\text { Avg \# } \\
\text { Persons }\end{array}$ & $\begin{array}{l}\text { Avg Days of } \\
\text { Service }\end{array}$ & & & & & $\begin{array}{c}\text { Avg } \\
\text { Storage } \\
\text { Liters }\end{array}$ \\
\hline $\begin{array}{c}5.33333333 \\
3\end{array}$ & 2.972222222 & & & & & $\begin{array}{c}473.0882 \\
4\end{array}$ \\
\hline & $\begin{array}{l}\text { Days of } \\
\text { Service }\end{array}$ & & & & & \\
\hline & 3 & & & & $\begin{array}{c}\text { Storage per } \\
\text { Week } \\
\text { (Liters) }\end{array}$ & $\begin{array}{c}1406.123 \\
4\end{array}$ \\
\hline
\end{tabular}




\section{Appendix D Nodal Demand}

\begin{tabular}{|c|c|c|c|c|c|c|}
\hline \multicolumn{7}{|c|}{ Corrected Nodal Demand gpm } \\
\hline & $\begin{array}{c}\text { Node } \\
\text { No }\end{array}$ & $\begin{array}{c}\text { No } \\
\text { House }\end{array}$ & $\begin{array}{c}x 6 \\
\text { people/house }\end{array}$ & $\begin{array}{c}\text { x 66 } \\
\text { L/person/day }\end{array}$ & $\begin{array}{c}x \\
1 \text { gal/4.5L }\end{array}$ & $\begin{array}{c}x(1 d a y / 24 \mathrm{hr}) x(\mathrm{I} \mathrm{hr} / \\
60 \mathrm{~min})\end{array}$ \\
\hline \multirow{12}{*}{ 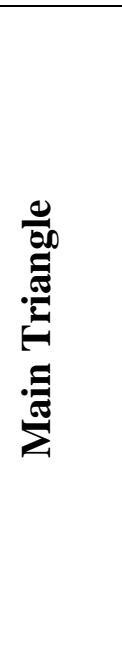 } & 11 & 35 & 210 & 13860 & 3080 & 2.138889 \\
\hline & 6 & 65 & 390 & 25740 & 5720 & 3.972222 \\
\hline & 9 & 10 & 60 & 3960 & 880 & 0.611111 \\
\hline & 8 & 63 & 378 & 24948 & 5544 & 3.85 \\
\hline & 16 & 5 & 30 & 1980 & 440 & 0.305556 \\
\hline & 17 & 20 & 120 & 7920 & 1760 & 1.222222 \\
\hline & 7 & 40 & 240 & 15840 & 3520 & 2.444444 \\
\hline & 14 & 40 & 240 & 15840 & 3520 & 2.444444 \\
\hline & 13 & 25 & 150 & 9900 & 2200 & 1.527778 \\
\hline & 3 & 5 & 30 & 1980 & 440 & 0.305556 \\
\hline & 5 & 5 & 30 & 1980 & 440 & 0.305556 \\
\hline & 4 & 15 & 90 & 5940 & 1320 & 0.916667 \\
\hline \multirow{6}{*}{ 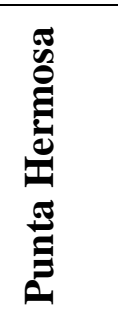 } & 24 & 15 & 90 & 5940 & 1320 & 0.916667 \\
\hline & 25 & 17 & 102 & 6732 & 1496 & 1.038889 \\
\hline & 26 & 17 & 102 & 6732 & 1496 & 1.038889 \\
\hline & 23 & 14 & 84 & 5544 & 1232 & 0.855556 \\
\hline & 21 & 30 & 180 & 11880 & 2640 & 1.833333 \\
\hline & 22 & 15 & 90 & 5940 & 1320 & 0.916667 \\
\hline \multirow{3}{*}{$\begin{array}{l}\tilde{z} \\
z \\
z\end{array}$} & 18 & 10 & 60 & 3960 & 880 & 0.611111 \\
\hline & 19 & 5 & 30 & 1980 & 440 & 0.305556 \\
\hline & 20 & 15 & 90 & 5940 & 1320 & 0.916667 \\
\hline Sum & & 466 & 2796 & 184536 & & \\
\hline
\end{tabular}




\section{Appendix E List of Supplemental EPANET Reports}

Files 1 thru 74 are full analysis reports produced by EPANET and can be found on the supplemental data $C D$.

1. Cerro Prieto Tank $12 \mathrm{ft} \&$ Bypass - $8 \mathrm{ft}$ min level

2. Cerro Prieto Tank $12 \mathrm{ft} \&$ Bypass - $10 \mathrm{ft}$ min level

3. Cerro Prieto Tank $14 \mathrm{ft} \&$ Bypass - 10ft min level

4. Cerro Prieto Tank $14 \mathrm{ft} \&$ Bypass - $12 \mathrm{ft}$ min level

5. Cerro Prieto Tank $16 \mathrm{ft} \&$ Bypass $-12 \mathrm{ft}$ min level

6. Cerro Prieto Tank $16 \mathrm{ft} \&$ Bypass - 14ft min level

7. Cerro Prieto Tank 16ft \& Bypass - 15.5ft min level

8. Cerro Prieto Tank 16ft \& Bypass - 15ft min level

9. Cerro Prieto Tank 16ft \& Bypass - 16ft min level

10. Cerro Prieto Tank Bypass - 2ft min level

11. Cerro Prieto Tank Bypass - 4ft min level

12. Cerro Prieto Tank Bypass - 6ft min level

13. Cerro Prieto Tank Bypass - 8ft min level

14. Cerro Prieto Scaled - 6 Inch Pipe 20

15. Cerro Prieto Scaled - 6 Inch Route

16. Cerro Prieto Scaled - 8 Inch Pipe 20

17. Cerro Prieto Scaled - 8 Inch Route

18. Cerro Prieto Scaled - 10 Inch Pipe 20

19. Cerro Prieto Scaled - 10 Inch Route

20. Cerro Prieto Scaled - $12 \mathrm{ft}$ Tank

21. Cerro Prieto Scaled - 12 Inch Pipe 20

22. Cerro Prieto Scaled - 12 Inch Route

23. Cerro Prieto Scaled - $14 \mathrm{ft}$ Tank

24. Cerro Prieto Scaled - $16 \mathrm{ft}$ Tank

25. Cerro Prieto Scaled - Loop 7 Pipe 10 3in long stretch

26. Cerro Prieto Scaled - Loop 7 Pipe 10 3in long stretch 4in

27. Cerro Prieto Scaled - Loop 7 Pipe 10 4in

28. Cerro Prieto Scaled - Loop 7 Pipe 10 in

29. Cerro Prieto Scaled - Loop 7 Pipe 11

30. Cerro Prieto Scaled - Loop 7 Pipe 11 3in long stretch 4in

31. Cerro Prieto Scaled - Loop 1 Pipe 21

32. Cerro Prieto Scaled - Loop 1 Pipe 22 
33. Cerro Prieto Scaled - Loop 1 Pipe 23

34. Cerro Prieto Scaled - Loop 1 Pipe 24

35. Cerro Prieto Scaled - Loop 2 Pipe 24

36. Cerro Prieto Scaled - Loop 2 Pipe 25

37. Cerro Prieto Scaled - Loop 3 Pipe 3 pipe 20 4in and 26 6in

38. Cerro Prieto Scaled - Loop 3 Pipe 3 pipe 20 4in

39. Cerro Prieto Scaled - Loop 3 Pipe 3 pipe 20 and 26 4in

40. Cerro Prieto Scaled - Loop 3 Pipe 12 pipe 20 4in

41. Cerro Prieto Scaled - Loop 3 Pipe 13

42. Cerro Prieto Scaled - Loop 3 Pipe 13 pipe 20 4in

43. Cerro Prieto Scaled - Loop 3 Pipe 14

44. Cerro Prieto Scaled - Loop 5 Pipe 10

45. Cerro Prieto Scaled - Loop 5 Pipe 15

46. Cerro Prieto Scaled - Loop 5 Pipe 16

47. Cerro Prieto Scaled - Loop 6 Pipe 5

48. Cerro Prieto Scaled - Loop 6 Pipe 5 Long Stretch 4in

49. Cerro Prieto Scaled - Loop 6 Pipe 5 Pipe 20 4in

50. Cerro Prieto Scaled - Loop 6 Pipe 6

51. Cerro Prieto Scaled - Loop 6 Pipe 6 Long Stretch 4in

52. Cerro Prieto Scaled - Loop 6 Pipe 7

53. Cerro Prieto Scaled - Loop 6 Pipe 7 Long Stretch 4in

54. Cerro Prieto Scaled - Loop 6 Pipe 8

55. Cerro Prieto Scaled - Loop 6 Pipe 8 Long Stretch 4in

56. Cerro Prieto Scaled - Loop 7 Pipe 6 3in long stretch 6in

57. Cerro Prieto Scaled - Loop 7 Pipe 6 4in long stretch 6in \& 2nd stretch 4 in

58. Cerro Prieto Scaled - Loop 7 Pipe 9 3in long stretch 4in

59. Cerro Prieto Scaled - Loop 7 Pipe 9 3in long stretch 6in

60. Cerro Prieto Scaled - Loop 7 Pipe 10

61. Cerro Prieto Scaled - Loop 3 Pipe 3 pipe 20 6in \& route 4 in

62. Cerro Prieto Scaled - Loop 3 Pipe 3 pipe 20 6in \& some more 4 in

63. Cerro Prieto Scaled - Loop 3 Pipe 4 pipe 20 6in \& route +4 in

64. Cerro Prieto Scaled - Loop 4 Pipe 3 Closed Pipe 204 in

65. Cerro Prieto Scaled - Loop 4 Pipe 12 Closed Pipe 204 in

66. PVC Prices Peru.xls

67. Cerro Prieto Scaled - Loop 4 Pipe 13 Closed

68. Cerro Prieto Scaled - Loop 4 Pipe 13 Closed Pipe 204 in

69. Cerro Prieto Scaled Loop Results.xlsx

70. Loop Scenarios Directory.xlsx

71. Cerro Prieto Scaled - Loop 3 Pipe 3 pipe 20 6in \& route +4 in 
72. Cerro Prieto Scaled - Loop 3 Pipe 3 pipe 20 \& some 4 in

73. Cerro Prieto Scaled - Loop 3 Pipe 3 pipe $20 \&$ some more 4 in

74. Cerro Prieto Scaled - Loop 3 Pipe 3 pipe 20 6in 


\section{Appendix F List of Supplemental Spreadsheets}

1. Cerro Prieto Diagnostic Survey Results

2. Cerro Prieto Water System Survey

3. Cerro Prieto methodology

4. Cerro Prieto Scaled Various Pressure Results

5. Cerro Prieto Scaled Loop Results

6. PVC Prices Peru 